1

3

\title{
Iron in silicate glasses and melts: implications for volcanological processes
}

\author{
C. Le Losq ${ }^{1,2}$, M. R. Cicconi ${ }^{2}$, D. R. Neuville ${ }^{2}$ \\ ${ }^{1}$ Research School of Earth Sciences, Australian National University, Building 142, Acton ACT 2601, \\ Australia \\ ${ }^{2}$ Géomatériaux, CNRS IPGP, Université de Paris, 1 rue Jussieu 75005 Paris, France
}

Corresponding author: C. Le Losq, lelosq@ipgp.fr 

While the deepest sections of the Earth (e.g. core) have a very high iron content, its superficial sections still contain moderate but non-negligible fractions of iron. The Earth core is estimated to contain mostly an alloy with a Fe/Ni ratio of $\sim 16$ (McDonough $\&$ s. Sun, 1995). Seismological data suggest the presence of $\sim 5 \%$ of light elements in this alloy (e.g. Jephcoat \& Olson, 1987; Badro et al., 2014), the best candidate being silicon, sulfur, carbon, oxygen, and hydrogen. Based on the composition of upper mantle xenoliths or on calculations assuming the average solar system element ratios, it is possible to estimate that the Earth mantle contains 7.2 to 8.1 wt\% FeO (Palme \& O'Neill, 2014).

Iron in igneous rocks mostly derives from the extraction of the iron from the upper mantle assemblage through partial melting. Mid-ocean ridge basalts, formed from the partial melting of $\sim 10 \%$ of the upper mantle below accretion regions, present an average concentration of $\mathrm{FeO}$ of $\sim 8 \mathrm{wt} \%$ to $12 \mathrm{wt} \%$ (Jenner \& O'Neill, 2012). The iron redox ratio, expressed hereby as $\mathrm{Fe}^{3+} / \mathrm{Fe}^{\text {TOT }}$ with $\mathrm{Fe}^{\mathrm{TOT}}=\mathrm{Fe}^{2+}+\mathrm{Fe}^{3+}$, in such glasses has been found to be comprised between 0.07 and 0.16 , with the latest estimates from X-Ray Absorption Near the Edge Structure (XANES) spectroscopy of 0.10(2) and 0.14(1) (Berry et al., 2018; H. Zhang et al., 2018), of 0.11(2) from wet-chemistry (Bézos \& Humler, 2005), and of 0.09(6) from Raman spectroscopy (Le Losq et al., 2019). Assuming a closed-system condition, such analyses place the average oxidation state of the upper mantle below accretion regions close to the Quartz-Fayalite-Magnetite (QFM) mineral redox buffer. Interestingly, arc basalt magmas present a more oxidized signature (above the QFM buffer), suggesting potentially a more oxidized character of the mantle wedge in subduction regions due to the presence of oxidized subduction fluids (e.g. Brounce et al., 2014). Observing extra-terrestrial primitive melts also reveals their enrichement into iron: the $\mathrm{FeO}$ content of the parental melts of martian shergottites is estimated at $16.7 \mathrm{wt} \%$ in average, and that of lunar glasses reach $22 \mathrm{wt} \%$ (Fig. 1). Iron is thus also a major element in extra-terrestrial magmas. Importantly, it most probably played a critical role on the geobiochemistry of planetary surfaces presenting extended solidified lava flows like Mars.

Depending on the crystallization series (tholeiitic or calc-alkaline), the iron concentration of more evolved melts can present different variations, but will ultimately decrease as evolved melts typically present low iron concentrations (Fig. 1). For instance, the rhyolite magma that was erupted during the $3.1 \mathrm{Ma}$ caldera-forming ignimbrite of the Mt Dore in France contains only 0.7 wt\% FeO (Le Losq \& Neuville, 2013).

In all cases, iron is prevalent in most igneous rocks, and plays a critical role in determining their properties, such as, for instance, their density and their viscosity. Among major elements in igneous rocks, iron has the particularity to present two different stable valences, $\mathrm{Fe}^{2+}$ and $\mathrm{Fe}^{3+}$, which, as we will see, play different roles in the structure of the melt, and, hence, differently influence their properties.

\section{Redox Equilibrium in Melts}

Reduction-Oxidation (redox) reactions involve the transfer of electrons between chemical species forming the redox couple of a given element, i.e. $\mathrm{Fe}^{2+}$ and $\mathrm{Fe}^{3+}$ in the case of iron. In silicate melts, oxygen is generally the electron carrier, such that the redox state (ratio of the different species) of iron is driven by changes in the oxygen chemical potential. Oxygen fugacity $\left(f \mathrm{O}_{2}\right)$ is conventionally used to describe the oxygen chemical potential. Redox equilibria in glass-forming melts have been exhaustively discussed by the early studies of Schreiber $(1986,1980,1987)$. In the case of iron, its redox equilibrium can be described as:

$$
4 F e_{\text {melt }}^{3+}+2 n O_{\text {melt }}^{2-}=4 F e_{\text {melt }}^{2+}+n O_{2}
$$




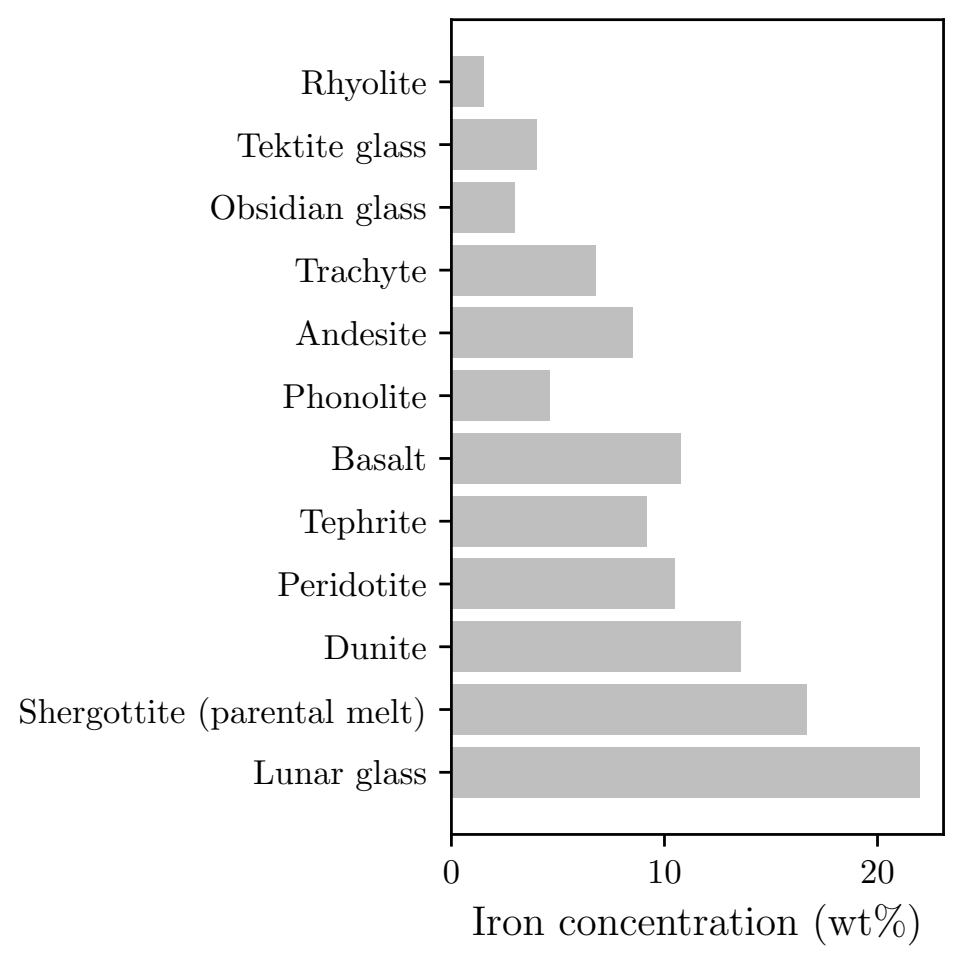

Figure 1. Examples of iron concentration ([FeO] equivalent) in various igneous rocks. Data from Geomatériaux - IPGP database, except for the average FeO content of the parental melts of shergottite meteorites estimated by Sossi et al. (2016). 


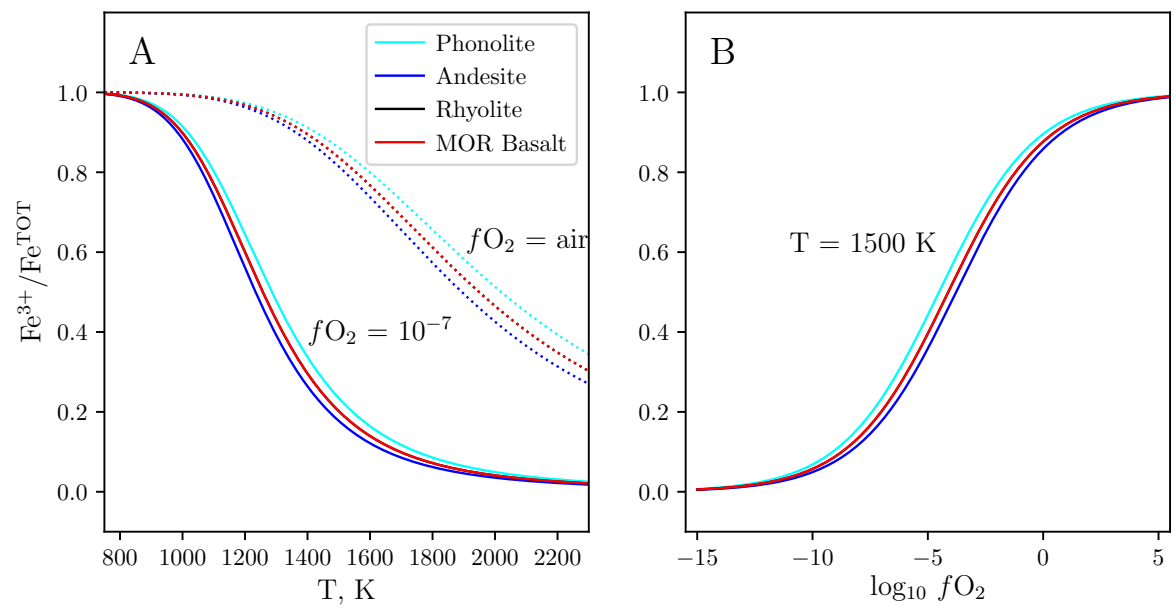

Figure 2. Variation of the $\mathrm{Fe}^{3+} / \mathrm{Fe}^{\mathrm{TOT}}\left(\mathrm{Fe}^{\mathrm{TOT}}=\mathrm{Fe}^{2+}+\mathrm{Fe}^{3+}\right)$ redox ratio as a function of (A) temperature and (B) oxygen fugacity, predicted by the model of Borisov et al. (2018) for typical phonolite (Erebus volcano lava bomb, Antartica), andesite (1902 eruption of Mt Pelée, France), rhyolite (3.1 Ma Ignimbrite of Mt Dore, France) and Mid-Ocean Ridge (MOR) basalt (mean composition from Gale et al., 2013) melts.

$$
\log \left(\frac{F e^{2+}}{F e^{3+}}\right)=-\frac{\Delta H}{2.303 R T}+b
$$

$\Delta H$ is endothermic, leading to iron reduction in silicate melts as temperature increases. The effect of the oxygen fugacity, $\mathrm{fO}_{2}$, an equivalent of the partial pressure of oxygen in the melt corrected for the nonideal character of $\mathrm{O}_{2}$ (e.g. see Albarède, 2011), is opposite to that of T: increasing $\mathrm{fO}_{2}$ favors the stabilization of $\mathrm{Fe}^{3+}$ species. Similarly to eq. 4 , this effect can be expressed as:

$$
-\log \left(f \mathrm{O}_{2}\right)=0.25 \log \left(\frac{F e^{2+}}{F e^{3+}}\right)+k
$$

The 0.25 term in eq. 5 arises from the fact that this constant usually equals to $\frac{n}{4}$ with $n$ the number of exchanged electrons, which is one in the case of the $\mathrm{Fe}^{2+} / \mathrm{Fe}^{3+}$ redox pair. For a given composition, and at constant temperature, the relationships described by eq. 5 should yield a straight line with slope equal to 0.25 . This has been experimentally corroborated by many studies (Fudali, 1965; Schreiber, 1986; Lauer \& Morris, 1977; Mysen et al., 1984). However, the melt composition influences this value, such that it may not be ideal in all cases. For example, Mysen et al. (1984) reported a slight decrease of the slope according to the ionic potential of the alkaline-earth cation in alkaline-earth silicate glasses. This trend is corroborated by the recent result of Cicconi et al. (2015), who observed that the mean ionic field strength of the alkali metal cations influences the slope of the eq. 5 relationship in multicomponent glasses.

Compared to the effects of oxygen fugacity and temperature, the impact of pressure on the oxidation state of iron has been the subject of few studies and remains not well known. In general, existing studies indicate that higher pressures promote reduced species in many multivalent compounds. For instance, reduction of $\mathrm{Fe}^{3+}, \mathrm{Cu}^{2+}$ and $\mathrm{Mn}^{3+}$ 



\subsubsection{Iron Environment in Melts and Glasses}

Ferric iron, $\mathrm{Fe}^{3+}$, is mainly regarded as 4 -fold coordinated, but higher coordination numbers have been also reported (Dyar, 1985; Virgo \& Mysen, 1985; Hannoyer et al., 1992; Galoisy et al., 2001; Farges et al., 2004; Métrich et al., 2006; Wilke et al., 2007; Rossano et al., 2007; Giuli et al., 2011, 2012; Mysen, 2006b). Interpretations of ${ }^{57} \mathrm{Fe}$ Mössbauer spectroscopy data by Mysen et al. (1985), Virgo and Mysen (1985) and Mysen (2006a) indicate $\mathrm{Fe}^{3+}$ in $\mathrm{CN} 4$ at $\mathrm{Fe}^{3+} / \mathrm{Fe}^{\mathrm{TOT}}>\sim 0.5$, and transferring toward a $\mathrm{CN} 6$ at lower $\mathrm{Fe}^{3+} / \mathrm{Fe}^{\text {TOT }}$ ratios. However, analysis of feldspar and haplo-thonalitic glasses by Rossano et al. (2007) suggest a more complex environment, with a wide range of coordinations, and variations with both composition and $\mathrm{Fe}^{3+} / \mathrm{Fe}^{\text {TOT }}$ of the glasses. Interpretations of Fe K-edge X-ray Absorption Spectroscopy (XAS) data seem to support such picture, showing $\mathrm{Fe}^{3+}$ present in alumino-silicate glasses mostly in $\mathrm{CN} 4$ and 5 environments (Wilke et al., 2007; Giuli et al., 2011, 2012; Métrich et al., 2006).

Ferrous iron, $\mathrm{Fe}^{2+}$, appears to have a diverse structural environment. The presence of $\mathrm{Fe}^{2+}$ in CN 6 has been reported (Calas \& Petiau, 1983; Virgo \& Mysen, 1985), along with trigonal bipyramidal and tetrahedral coordination (Waychunas et al., 1988; Jackson et al., 1993; Rossano et al., 2007). $\mathrm{Fe}^{2+}$ thus appears to have an average coordination close to 5, which could be possibly translated as a coexistence of 4-, 5- and 6- or just the simultaneous presence of 4- and 6- fold $\mathrm{Fe}^{2+}$ coordinated (Cicconi et al., 2015).

\subsubsection{Melt composition and iron oxidation state}

The link between melt composition and iron oxidation state can be understood using different concepts; among those, one of the most successfull is that of optical basicity (Moretti \& Ottonello, 2003; Duffy \& Ingram, 1976; Ottonello et al., 2001; Duffy, 1993). According to Duffy (1993), optical basicity is based on orbital expansion effects reflecting the nature of the chemical bonding between a Lewis acid-base pair; in oxide glasses, oxygens act as bases in the Lewis sense (i.e. as a donor of electron pairs) while metals act as acids. Indeed, the charge balance of the different types of oxygen atoms in the melt can be expressed as (Fincham \& Richardson, 1954):

$$
2 O^{-}=O^{0}+O^{2-}
$$

with $\mathrm{O}^{-}, \mathrm{O}^{0}$ and $\mathrm{O}^{2-}$ non-bridging, bridging and "free" oxygens in the melt, respectively. The equilibrium constant $K$ of eq. 6 is equal to:

$$
K=\frac{\left[O^{2-}\right]\left[O^{0}\right]}{\left[O^{-}\right]^{2}}
$$

assuming that activities of the different oxygen species are equal to their molar concentrations. The free energy of mixing per mole of melt is:

$$
\Delta G^{\text {mixing }}=\frac{\left[O^{-}\right]}{2} \times R \times T \times \ln (K)
$$

with $\mathrm{R}$ the perfect gas constant and $\mathrm{T}$ the temperature. An important point is that different metal cations affect $K$, and thus the fractions of the oxygen species, differently. An important point of considering silicate glasses and melts through eq. 6 is that such materials presents the characteristics of an acid-base reaction, defined by Flood et al. (1947) as "the transfer of an oxygen ion from a state of polarisation to another". The link between acid-base and redox exchanges in melts can thus be represented by the "normal oxygen electrode": 


$$
\frac{1}{2} O^{2}+2 e^{-}=O^{2-}
$$

Melt polymerization is affected by the Lux-Flood acid-base properties of dissolved oxides, with the involvements of free oxygens (Fraser, 1975, 1977):

$$
\begin{gathered}
M O+O^{2-}=M O_{2}^{2-} \\
M O=M^{2+}+O^{2-}
\end{gathered}
$$

Eqs. 10 and 11 respectively describe the acidic and basic reactions between the $M$ central cations and the oxygen ligands $\left(\mathrm{O}^{2-}\right.$ and $\left.\mathrm{O}^{-}\right)$in silicate melts. The mean polarization state of the oxygen ligands and their ability to transfer fractional electronic charge to the $\mathrm{M}$ cation is represented by the optical basicity $\Lambda$ of the system. It is defined as the ratio of the Jørgensen's function (Jørgensen, 1962) of the ligand in the polarization state of interest over that in an unpolarised state (free $\mathrm{O}^{2-}$ ions in an oxidic medium of reference). Different metal cations have different electronic properties and thus different oxide basicity (Table 1). It is possible to calculate the glass optical basicity from the oxide optical basicities using the following expression:

$$
\Lambda=\sum_{i} X_{O^{i}} \Lambda_{i}
$$

with $X_{O^{i}}$ the proportions of oxygen atoms the $i^{\text {th }}$ oxide contributes, and $\Lambda_{i}$ its oxygen basicity (e.g. see Table 1). For instance, for the $\mathrm{CaSiO}_{3}$ glass, obtained from the mixture of $50 \mathrm{~mol} \% \mathrm{CaO}$ and $50 \mathrm{~mol} \% \mathrm{SiO}_{2}, \Lambda$ CaSiO $3=\frac{1}{3} \times 1.00+\frac{2}{3} \times 0.48=0.65$.

\begin{tabular}{lc}
\hline Oxide & $\Lambda_{i}$ \\
\hline $\mathrm{SiO}_{2}$ & 0.48 \\
$\mathrm{Al}_{2} \mathrm{O}_{3}$ & 0.59 \\
$\mathrm{TiO}_{2}$ & 0.58 \\
$\mathrm{FeO}$ & 0.48 \\
$\mathrm{Fe}_{2} \mathrm{O}_{3}$ & 0.48 \\
$\mathrm{MgO}$ & 0.78 \\
$\mathrm{CaO}$ & 1.00 \\
$\mathrm{SrO}$ & 1.03 \\
$\mathrm{BaO}$ & 1.12 \\
$\mathrm{H}_{2} \mathrm{O}$ & 0.39 \\
$\mathrm{Li}_{2} \mathrm{O}$ & 1.00 \\
$\mathrm{Na}_{2} \mathrm{O}$ & 1.15 \\
$\mathrm{~K}_{2} \mathrm{O}$ & 1.36 \\
\hline
\end{tabular}

Table 1. Example of optical basicity $\Lambda$ of common network formers and modifiers / charge compensators in silicate melts. Values from Ottonello et al. (2001).

Optical basicities of silicate glasses correlates well with the oxidation state of iron in the melt equilibrated at given T- $f \mathrm{O}_{2}$ conditions (Schreiber et al., 1994; Ottonello et al., 
2001; Moretti \& Ottonello, 2003). Network former cations present close optical basicity in silicate glasses, and thus their influences on the iron oxidation state may be considered as analogous (Mysen et al., 1985; Sack et al., 1981; Kilinc et al., 1983b). In detail, changing the melt $\mathrm{Al} /\left(\mathrm{Al}+\mathrm{Si}\right.$ ) leads to small changes in its $\mathrm{Fe}^{3+} / \mathrm{Fe}^{\mathrm{TOT}}$ (e.g. Mysen et al., 1985; Borisov et al., 2015). Metal cations present higher optical basicity than network former cations (Table 1), such that increasing their fraction generally promotes oxidation (Schreiber et al., 1994; Mysen et al., 1984) because increasing the melt basicity results in a shift of eq. 1 toward the oxidized species. However, different metal cations present different $\Lambda$ values (Table 1), such that the effect of individual cations on the glass oxidation state is complex.

In particular, the effect of the $\mathrm{M}$ cation depends on both the $\mathrm{Al} /(\mathrm{M}+\mathrm{Al})$ ratio of the glass and the $\mathrm{M}$ cation electronic properties. The effect of the $\mathrm{Al} /(\mathrm{Al}+\mathrm{M})$ ratio can be rationalized considering the fact that trivalent iron in polyhedral coordination will present a charge deficit that requires charge balance by metal cations. At $\mathrm{Al} /(\mathrm{Al}+\mathrm{M})<$ 1 , metal cations play a dual role of network modifiers and charge compensators, and, upon addition of trivalent cations, network modifiers can change their role into charge compensator to ensure charge balance of polyhedral units carrying trivalent cations, as shown for Ca (Neuville et al., 2004) or Na (Le Losq et al., 2014). At $\mathrm{Al} /(\mathrm{Al}+\mathrm{M}) \geq 1$ and assuming that $\mathrm{Fe}^{3+}$ plays a role of network former, introduction of $\mathrm{Fe}^{3+}$ in the network will be difficult as metal cations will already be charge compensators of $\mathrm{Al}$, such that a competition between $\mathrm{Al}$ and $\mathrm{Fe}^{3+}$ for charge compensation will occur. Furthermore, $\mathrm{Fe}^{2+}$ will be promoted as it will be able to participate in charge compensating Al-bearing polyhedral units. From those considerations, we expect $\mathrm{Fe}^{3+}$ to be stable in peralkaline compositions $(\mathrm{Al} /(\mathrm{M}+\mathrm{Al})<0.5)$ and suppressed in peraluminous compositions $(\mathrm{Al} /(\mathrm{Al}+\mathrm{M}) \geq$ 1). The data of Dickenson and Hess (1982) in $\mathrm{K}_{2} \mathrm{O}-\mathrm{FeO}-\mathrm{Al}_{2} \mathrm{O}_{3}-\mathrm{SiO}_{2}$ melts seem to confirm this hypothesis: they clearly show that the $\mathrm{Fe}^{3+}$ fraction is not varying much with $\mathrm{Al} /(\mathrm{Al}+\mathrm{M})$ in peralkaline melts, but decreases with increasing $\mathrm{Al} /(\mathrm{Al}+\mathrm{M})$ at values higher than $\sim 0.5$, highlighting the conversion of $\mathrm{Fe}^{3+}$ into $\mathrm{Fe}^{2+}$ due to increasing the need for $\mathrm{Al}$ charge compensation 3. Borisov et al. (2017) recently questioned such link on the basis of scatter in the data of Dickenson and Hess (1982) at high $\mathrm{Fe}^{3+} / \mathrm{Fe}^{\mathrm{TOT}}$ ratios and on the absence of such a relationship between $\mathrm{Al} /(\mathrm{Al}+\mathrm{K})$ and iron oxidation state in their study. However, the potassic melts studied by Borisov et al. (2017) also contained significant amounts of $\mathrm{MgO}$ and $\mathrm{CaO}$, such that $\mathrm{Al} /(\mathrm{Al}+\mathrm{M})($ with $\mathrm{M}=\mathrm{Na}+\mathrm{K}+\mathrm{Mg}+\mathrm{Ca}$ ) was never $\geq 0.5$ in their samples. Their data are thus not relevant to comment on the links between $\mathrm{Al} /(\mathrm{Al}+\mathrm{M})$ and $\mathrm{Fe}^{3+} / \mathrm{Fe}^{\mathrm{TOT}}$ in the peraluminous domain.

Despite this, the data of Borisov et al. (2017) shed light on the fact that increasing the fractions of $\mathrm{Ca}, \mathrm{Na}$ or $\mathrm{K}$ in natural melts yields an increase of the $\mathrm{Fe}^{3+} / \mathrm{Fe}^{\mathrm{TOT}}$ ratio in peralkaline melts. Data from Mysen et al. (1985) in Ca aluminosilicate melts also reveal a decreasing $\mathrm{Fe}^{3+} / \mathrm{Fe}^{\text {TOT }}$ with increasing alkaline-earth metal concentration in aluminosilicate melts, and, hence, with increasing their degree of depolymerisation. Those observations agree with earlier data from simple silicate melts of Paul and Douglas (1965), which indicate that increasing the alkali content in binary alkali silicate glasses at fixed $\mathrm{T}$ and $f \mathrm{O}_{2}$ leads to increasing $\mathrm{Fe}^{3+} / \mathrm{Fe}^{\mathrm{TOT}}$. However, all observations are not unanimous regarding the correlations between metal cation concentrations and iron oxidation state. For instance, Tangeman et al. (2001) reported a decrease in $\mathrm{Fe}^{3+} / \mathrm{Fe}^{\mathrm{TOT}}$ with increasing $\left[\mathrm{K}_{2} \mathrm{O}\right]$ in $\mathrm{K}_{2} \mathrm{O}-\mathrm{FeO}-\mathrm{SiO}_{2}$ glasses, and increases in $\mathrm{Fe}^{3+} / \mathrm{Fe}^{\mathrm{TOT}}$ with increasing $\left[\mathrm{Na}_{2} \mathrm{O}\right]$ and $[\mathrm{CaO}]$ in other binary silicate glasses.

Such complexities indicate that the concentration of metal cations by itself is not sufficient to understand the variations of iron oxidation state with melt composition. Other parameters must be taken into account, such as melt overall degree of polymerisation, $\mathrm{Al} /(\mathrm{Al}+\mathrm{Si})$ and $\mathrm{Al} /(\mathrm{A}+\mathrm{M})$ ratios, as well as the ionic field strength of the metal cations in the melt. Indeed, the ionic field strength of metal cations, which plays an important role on the melt structure, correlates with the iron oxidation state (Fig. 4A). Increas- 


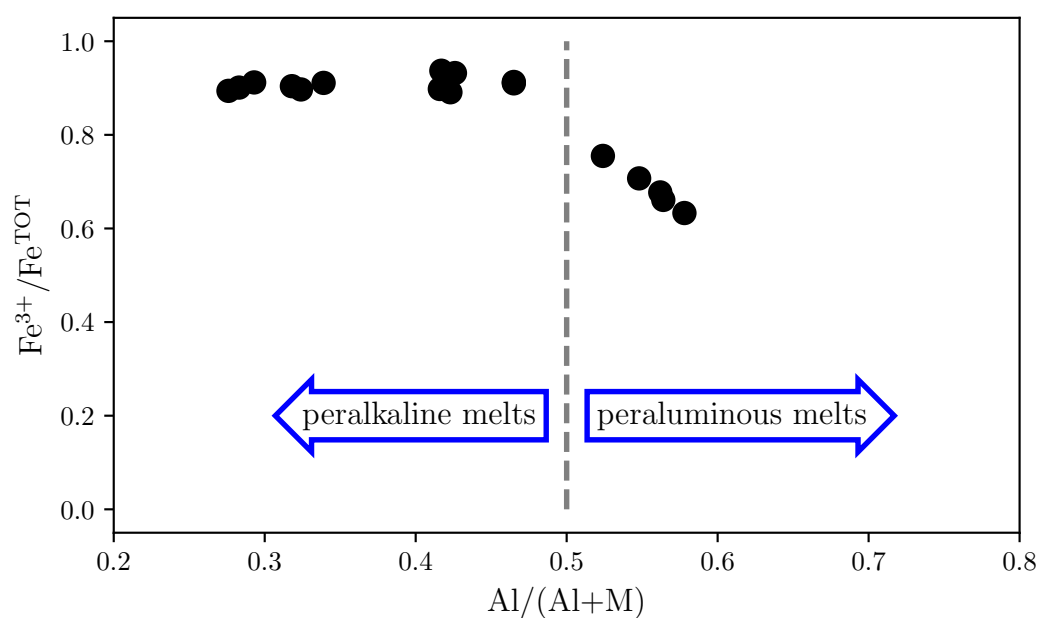

Figure 3. Iron oxidation state in $\mathrm{K}_{2} \mathrm{O}-\mathrm{Al}_{2} \mathrm{O}_{3}-\mathrm{SiO}_{2}-\mathrm{FeO}$ melts at $1673 \mathrm{~K}$ in air as a function of the melt $\mathrm{Al} /(\mathrm{Al}+\mathrm{M})$ molar ratio. The dotted line highlight the tectosilicate join $(\mathrm{Al} /(\mathrm{Al}+\mathrm{M})=$ 1). Data from Dickenson and Hess (1982).

ing the ionic field strength of metal cations results in decreasing $\mathrm{Fe}^{3+} / \mathrm{Fe}^{\text {TOT }}$. According to this, it is expected that mixing metal cations will produce variations in $\mathrm{Fe}^{3+} / \mathrm{Fe}^{\mathrm{TOT}}$ at fixed $\mathrm{T}$ and $f \mathrm{O}_{2}$ conditions. This is confirmed by the study of Cicconi et al. (2015) on phonolite melts, which revealed an increasing $\mathrm{Fe}^{3+} / \mathrm{Fe}^{\mathrm{TOT}}$ with increasing the $\mathrm{K} /(\mathrm{K}+\mathrm{Na})$ ratio in phonolite magmas, at both oxidized and reduced conditions (Fig. 4B).

In addition of metal cations, volatile elements can further play a role on the oxidation state of iron. Considering water, the activities of $\mathrm{Fe}^{2+}$ and $\mathrm{Fe}^{3+}$ change with water content (Gaillard et al., 2003). As a result, the ratio $\mathrm{Fe}^{3+} / \mathrm{Fe}^{\mathrm{TOT}}$ tends to increase in hydrous magmas under reduced conditions, while effects under oxidized conditions are more difficult to distinguish (Gaillard et al., 2003; Moretti, 2005). Sulfur forms a redox couple with iron, such that changes in the redox of one affects that of the other element. Considering $\mathrm{S}$ as present mostly as $\mathrm{S}^{2-}$ and $\mathrm{S}^{6+}$ in magmas, we have:

$$
S^{6+}+8 e^{-}=S^{2-}
$$

and combining it with the reaction

$$
F e^{3+}+e^{-}=F e^{2+}
$$

we obtain the redox couple

$$
S^{2-}+8 F e^{3+}=S^{6+}+8 F e^{2+}
$$

We see there that a small change in $\mathrm{S}$ oxidation state can result in larger changes in that of Fe because of the high number of exchanged electrons involved in the redox reaction described by eq. 15. As a result, sulfur degassing can affect $\mathrm{Fe}^{3+} / \mathrm{Fe}^{\mathrm{TOT}}$ in magmas (e.g. Moussallam et al., 2014). However, one should remember that in magmas, as in any reacting system, the redox buffer is imposed by a highly abundant component speciating in a reduced and oxidized form. As a result, as Fe is the main multivalent transition element in magmas, their average oxidation state will be generally driven by that of Fe.

Generally, variations of iron redox ratio with melt composition must further be considered with keeping in mind that $\mathrm{Fe}^{2+}$ and $\mathrm{Fe}^{3+}$ have different roles in the glass structure. $\mathrm{Fe}^{2+}$ is commonly considered as a network modifier element, and $\mathrm{Fe}^{3+}$ mainly acts 

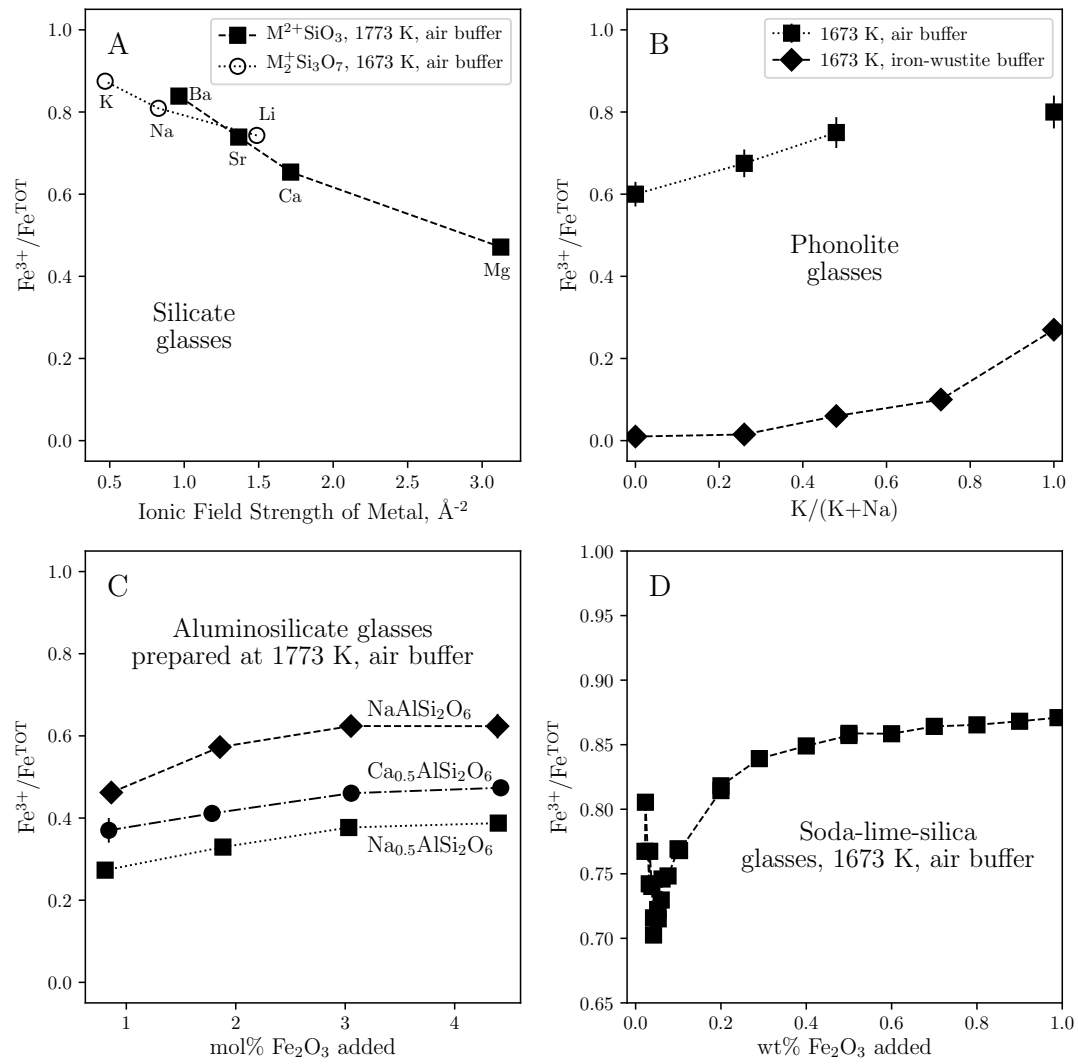

Figure 4. Examples of compositional effects on the oxidation state of iron in magmas. (A) Generally, the ionic field strength of metal cations in melts directly influences the iron oxidation state (ionic field strength calculated for a coordination state of 6 with radius from (Whittaker \& Muntus, 1970)). (B) Mixing of different metal cations can lead to linear or non-linear variations of the iron oxidation state at constant $\mathrm{T}$ and $f \mathrm{O}_{2}$. (C) Increasing the concentration of iron in magmas leads to an oxidation of iron. (D) In dilute concentrations, the relationship between iron oxidation state and concentration seem to become complicated. Curves are guides to the eyes. Data are from Densem and Turner (1938); Mysen et al. (1984); Mysen (2006b); Cicconi et al. (2015); Paul and Douglas (1965).

as a network former element, as shown for instance by Extended X-ray Absorption Fine Structure data (Cicconi et al., 2015) and viscosity data (see section 3.2.1). Interestingly, the change of the melt viscosity at given temperature as a function of the Fe oxidation state further depends on the metal cation in the melt, illustrating the interplay between metal cations and $\mathrm{Fe}^{3+}$ for charge compensation (see section 4.2 and figure 5). Furthermore, $\mathrm{Fe}^{3+}$ is present as an amphoteric oxide in silicate melts and glasses, i.e. it acts either as an acidic or basic oxide, depending on the bulk system basicity. As a consequence, $\mathrm{Fe}_{2} \mathrm{O}_{3}$ can either react with bridging or with non-bridging oxygens (Ottonello et al., 2001; Moretti, 2005), and the role of $\mathrm{Fe}^{3+}$ in the melt/glass structure is a complex function of the overall system basicity that is dictated by its chemical composition. Another important point of consideration is that, at given $\mathrm{T}-\mathrm{f} \mathrm{O}_{2}$ conditions, the concentration of iron affects its oxidation state (Fig. 4C,D). According to the recent data of Mysen (2006a) or to the older data of Densem and Turner (1938), this effect can shift the oxidation state of iron of $\sim 0.2 \mathrm{Fe}^{3+} / \mathrm{Fe}^{\text {TOT }}$. In dilute concentration, it becomes complex as suggested 
by the data of Densem and Turner (1938). The latter show that, when adding tens to hundreds of ppm of $\mathrm{Fe}_{2} \mathrm{O}_{3}$ in a soda-lime-silica glass in air at $1400{ }^{\circ} \mathrm{C}, \mathrm{Fe}^{3+} / \mathrm{Fe}^{\mathrm{TOT}}$ first decreases of $\sim 0.1$, and then increase of $\sim 0.2$ with further addition of $\mathrm{Fe}_{2} \mathrm{O}_{3}$. Such behavior could point to different interactions between $\mathrm{Fe}^{3+} / \mathrm{Fe}^{2+}$ and the network cations at dilute or high concentrations, but, to conclude on this point, the data of Densem and Turner (1938) need to be corroborated by another study because this contrasting behaviour could also arise from an analytical effect.

\section{Physical Properties: Highlights on Density and Viscosity}

The mobility of magmas within the Earth mantle and crust, as well as within superficial volcanic system is determined by two factors: melt density $\rho$ and viscosity $\eta$. The former directly determines the melt buoyancy while the latter reflects the internal force resisting uniform melt flow. The importance of $\rho$ and $\eta$ is illustrated by the expression of the eruption rate $Q$ of a magma ascending into a volcanic conduit of uniform radius a (Jaupart, 1996):

$$
Q=\rho \frac{a^{4}}{8 \eta}\left(-\frac{d P}{d z}-\rho g\right)
$$

with $g$ the gravitational acceleration and $\frac{d P}{d z}$ the vertical pressure gradient. Therefore, the influence of iron on the exchange of matter in igneous geologic systems will be determined by its direct and indirect effects on the density and viscosity of magmas and lavas.

\subsection{Influence of Iron Content and Redox on the Density of Melts}

In general, addition of iron will result in increasing the melt density, due to the large molar mass of iron. Changing the iron oxidation state in the melt will further induce changes in the melt density, because $\mathrm{Fe}^{2+}$ and $\mathrm{Fe}^{3+}$ present different partial molar volumes. Regarding $\mathrm{Fe}^{2+}$, Lange and Carmichael (1987) reported a partial molar value of $13.65 \pm$ $0.15 \mathrm{~cm}^{3} \mathrm{~mol}^{-1}$ for the oxide component $\mathrm{FeO}$ at $1400{ }^{\circ} \mathrm{C}$ from density measurements in multicomponent alumino-silicate melts, which agree with the general values of $12.8-14.0$ $\mathrm{cm}^{3} \mathrm{~mol}^{-1}$ at $1400{ }^{\circ} \mathrm{C}$ reported in silica-rich melts (Bottinga \& Weill, 1970; Mo, 1982; Bottinga et al., 1982; D. B. Dingwell et al., 1988; Lange \& Carmichael, 1989; Liu, 2006). However, in silica-poor ferrosilicate, the partial molar volume of $\mathrm{FeO}$ at $1400{ }^{\circ} \mathrm{C}$ approaches $15.8 \mathrm{~cm}^{3} \mathrm{~mol}^{-1}$, as shown by the data of Shiraishi et al. (1978) for instance. Therefore, the partial molar volume of $\mathrm{FeO}$ is composition dependent, a fact that can be explained by taking into account variations in the $\mathrm{Fe}^{2+}$ local environment with melt composition.

Regarding $\mathrm{Fe}^{3+}$, early reports from Lange and Carmichael (1987) and D. B. Dingwell et al. (1988) indicated partial molar volumes of $\mathrm{Fe}_{2} \mathrm{O}_{3}$ of $42.13 \pm 0.28 \mathrm{~cm}^{3} \mathrm{~mol}^{-1}$ and $40.69 \pm 0.80 \mathrm{~cm}^{3} \mathrm{~mol}^{-1}$ at $1400{ }^{\circ} \mathrm{C}$, respectively. In $\mathrm{Na}_{2} \mathrm{O}-\mathrm{FeO}-\mathrm{Fe}_{2} \mathrm{O}_{3}-\mathrm{SiO}_{2}$ melts, Lange and Carmichael (1989) later reported a value of $41.78 \pm 0.41 \mathrm{~cm}^{3} \mathrm{~mol}^{-1}$ at $1400{ }^{\circ} \mathrm{C}$. The recent study of Liu (2006) report a similar value of $41.52 \pm 0.34 \mathrm{~cm}^{3} \mathrm{~mol}^{-1}$ from high temperature density measurements in $\mathrm{Na}_{2} \mathrm{O}-\mathrm{FeO}-\mathrm{Fe}_{2} \mathrm{O}_{3}-\mathrm{SiO}_{2}$ and $\mathrm{K}_{2} \mathrm{O}-\mathrm{FeO}-\mathrm{Fe}_{2} \mathrm{O}_{3}-\mathrm{SiO}_{2}$ melts. Those data suggest that the partial molar volume of $\mathrm{Fe}_{2} \mathrm{O}_{3}$ is independent of temperature and composition in such melt compositions, and further indicate a $\mathrm{Fe}^{3+}$ coordination number comprised between 4.5 and 5.0. The results of Liu (2006) tend to indicate that the partial molar volume of $\mathrm{Fe}_{2} \mathrm{O}_{3}$ could be independent of composition over an extended range of melt chemical composition (from alkali silicate to magmatic liquids). However, data from Lange and Carmichael $(1987,1989)$ contradict this, showing a slight dependence of the partial molar volume of $\mathrm{Fe}_{2} \mathrm{O}_{3}$ on temperature. 
Previously reported partial molar values for $\mathrm{FeO}$ and $\mathrm{Fe}_{2} \mathrm{O}_{3}$ were obtained from density measurements at high temperature in melts, but at room pressure. Increasing pressure changes the overall coordination states of the ions in the melt. The transition of $\mathrm{Al}$ from mostly four-fold to mostly six-fold coordination occurs at pressures lower than 15 GPa (Yarger et al., 1995; Allwardt, 2005a; Guillot \& Sator, 2007), a phenomenon further enhanced by temperature in aluminium-rich compositions (Allwardt, 2005b; Le Losq et al., 2014) . Similarly, Si will undergo a change in its coordination, from a four-fold to a six-fold site, at pressure comprised between 10 and $50 \mathrm{GPa}$ (Guillot \& Sator, 2007; Lee et al., 2008; Sanloup, Drewitt, Konôpková, et al., 2013; Y. Wang et al., 2014). This transition to higher coordination numbers with increasing pressure also affects network modifier cations, such as $\mathrm{Ca}^{2+}, \mathrm{Mg}^{2+}$ and $\mathrm{Fe}^{2+}$ (Guillot \& Sator, 2007; Sun et al., 2011; Sanloup, Drewitt, Crépisson, et al., 2013). Accordingly, it is expected that $\mathrm{Fe}^{3+}$ coordination state also transitions toward higher number, as $\mathrm{Al}^{3+}$ does. As a result, while the reported models of magma density may be relevant for sub-crustal pressure, any estimation at pressure higher than a few GPa will be affected by systematic errors due to changes in the coordination state of network former and network modifier cations in melts. Those changes in coordination of all major elements with pressure yield densification of magmas at depth, which can result in controlling the partioning of elements or the mobility of deep melt through density traps (Sanloup, 2016).

\subsection{Iron and the Viscosity of Silicate Melts}

As previously discussed, $\mathrm{Fe}^{2+}$ and $\mathrm{Fe}^{3+}$ have different roles in the structure of melts, with $\mathrm{Fe}^{2+}$ acting as a network modifier element and $\mathrm{Fe}^{3+}$ as a weak network former element. This agrees with the observed dependence of melt viscosity on iron concentration and oxidation state. Upon iron addition in a melt with a composition equal to the eutectic anorthite-diopside $\left(\mathrm{CaAl}_{2} \mathrm{Si}_{2} \mathrm{O}_{8}-\mathrm{CaMgSi}_{2} \mathrm{O}_{6}\right)$, the data from Chevrel et al. (2013) show that melt viscosity decreases with increasing iron concentration (Fig. 5A). We note that this effect is enhanced at undercooled temperatures where entropic effects due to chemical mixing of elements and structural disorder become important. Similarly, substituting $\mathrm{CaO}$ by $\mathrm{FeO}$ in the diopside melt composition results in a similar decrease in viscosity at undercooled temperatures (Fig. 5B and Table 2) where such melts mostly contain iron in its $3+$ valence (calculation from the (Kress \& Carmichael, 1991) model for CaFe-Al-Si-O melts). Therefore, those data together with those in Fig. 5A indicate that $\mathrm{Fe}^{3+}$ appears to act more like a network modifier than like a "traditional" network former as $\mathrm{Al}^{3+}$.

The comparison between the compositions $\mathrm{NaAlSi}_{3} \mathrm{O}_{8}$ and $\mathrm{NaFeSi}_{3} \mathrm{O}_{8}$ further shed light on the role of $\mathrm{Fe}^{3+}$ on melt viscosity (Fig. 6). If, from a structural point of view, $\mathrm{Fe}^{3+}$ can be considered as a network former when in tetrahedral state (e.g. (Mysen et al., 1985)), viscosity data indicate that it does not participate in building a strong network and, hence, acts similarly as a network modifier on melt viscosity (Figs. 5, 6). This probably is due to its ionic field strength that is much weaker than that of $\mathrm{Al}^{3+}$, for instance. In line with such comment, D. B. Dingwell and Virgo (1988) noted that the relative viscosity of alumino-, ferro-and gallio-silicates are inversely correlated with the electronegativity of the trivalent cations, and assigned this to changes in the ionic character of the $\mathrm{X}^{3+}{ }_{-} \mathrm{O}^{2-}$ bonds (with $\mathrm{X}$ any trivalent cation like $\mathrm{Al}, \mathrm{Ga}$ or $\mathrm{Fe}$ ) that ultimately influence melt structure and viscosity. Increasing the ionic character of the $\mathrm{X}^{3+}-\mathrm{O}^{2-}$ bonds explains the decrease of viscosity observed when replacing $\mathrm{Al}^{3+}$ by $\mathrm{Fe}^{3+}$ in albitic melts, as shown in Figure 6.

At fixed melt composition, changing the oxidation state of iron further induces changes in the viscosity of the melt (Figure 7). At superliquidus temperatures, the measurements reported by D. B. Dingwell and Virgo $(1987)$ and D. B. Dingwell $(1989,1991)$ on ferrosilicate melts indicate that a decrease of the $\mathrm{Fe}^{3+} / \mathrm{Fe}^{\mathrm{TOT}}$ proportion from 0.9 down to 0.2 induces a decrease of viscosity by $\sim 0.5 \log$ units. This is consistent with data on 

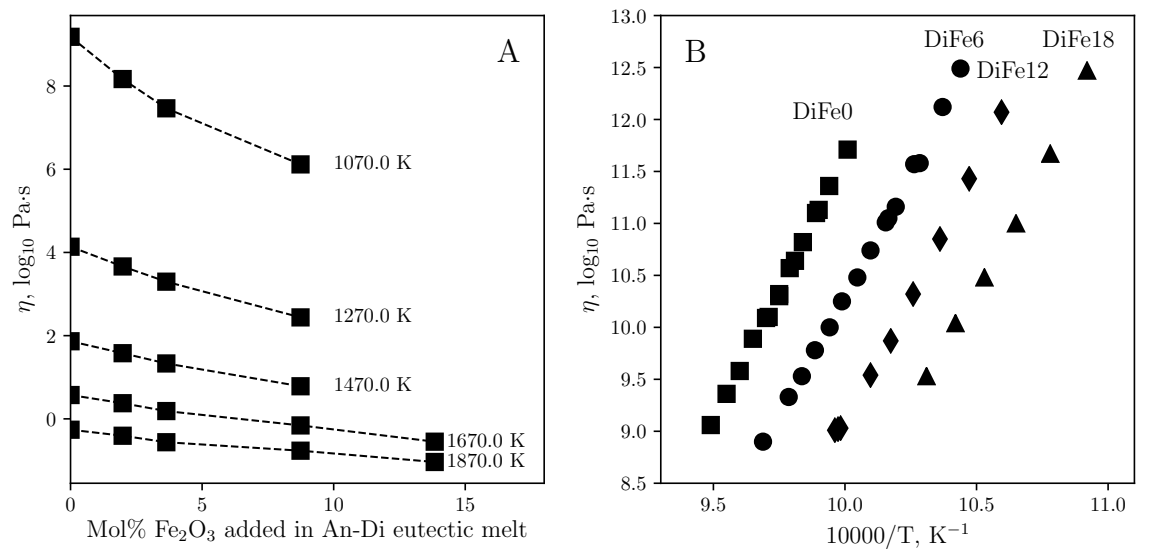

Figure 5. Viscosity of A) anorthite-diopside (An-Di) eutectic melt as a function of added iron, and $\mathrm{B}$ ) of diopside melts in which $\mathrm{CaO}$ is replaced by $\mathrm{FeO}$. In $\mathrm{A}$ ), lines are guides for the eyes; data are from Chevrel et al. (2013). In B), DiFe0, DiFe6, DiFe12 and DiFe18 melts are compositions where $\mathrm{CaO}$ was replaced by $\mathrm{FeO}$ in proportions equal to 0, 6, 12 and $18 \mathrm{~mol} \%$. $\mathrm{Fe}^{3+} /\left(\mathrm{Fe}^{2+}+\mathrm{Fe}^{3+}\right)$ redox ratio of those melts is higher than $98 \%$ according to the model of Kress and Carmichael (1991); see Table 2 for data.

Table 2. Viscosity data of $\mathrm{DiFe} 0, \mathrm{DiFe}, \mathrm{DiFe} 12$ and DiFe18 melts, where $\mathrm{CaO}$ was replaced by $\mathrm{FeO}$ in proportions equal to $0,6,12$ and $18 \mathrm{~mol} \%$. Viscosity was measured following the method of Neuville (2006) between 915 and $1053 \mathrm{~K}$, such that their $\mathrm{Fe}^{3+} /\left(\mathrm{Fe}^{2+}+\mathrm{Fe}^{3+}\right)$ redox ratio is higher than $98 \%$ according to the model of Kress and Carmichael (1991).

\begin{tabular}{llllllll}
\hline \multicolumn{2}{c}{ DiFe0 } & \multicolumn{2}{c}{ DiFe } & \multicolumn{2}{c}{ DiFe12 } & \multicolumn{2}{c}{ DiFe18 } \\
$\mathrm{T}, \mathrm{K}$ & $\mathrm{Pa} \cdot \mathrm{s}$ & $\mathrm{T}, \mathrm{K}$ & $\mathrm{Pa} \cdot \mathrm{s}$ & $\mathrm{T}, \mathrm{K}$ & $\mathrm{Pa} \cdot \mathrm{s}$ & $\mathrm{T}, \mathrm{K}$ & $\mathrm{Pa} \cdot \mathrm{s}$ \\
\hline 1053.7 & 10.06 & 957.9 & 13.49 & 982.9 & 10.87 & 915.8 & 13.47 \\
1047.1 & 10.36 & 972.4 & 12.58 & 943.8 & 13.07 & 927.6 & 12.67 \\
1041.7 & 10.58 & 984.7 & 12.01 & 954.9 & 12.43 & 939.0 & 12.00 \\
1036.3 & 10.89 & 995.3 & 11.48 & 965.2 & 11.85 & 949.7 & 11.48 \\
1030.9 & 11.09 & 1005.9 & 11.00 & 974.8 & 11.32 & 959.7 & 11.04 \\
1029.9 & 11.10 & 1016.7 & 10.53 & 990.4 & 10.54 & 969.9 & 10.53 \\
1025.6 & 11.30 & 964.2 & 13.12 & 1001.7 & 10.03 & & \\
1025.6 & 11.32 & 974.4 & 12.57 & 1002.6 & 10.02 & & \\
1021.5 & 11.57 & 983.8 & 12.05 & 1003.9 & 10.01 & & \\
1019.4 & 11.64 & 990.4 & 11.74 & & & & \\
1016.3 & 11.82 & 1001.2 & 11.25 & & & & \\
1011.1 & 12.10 & 1011.6 & 10.78 & & & & \\
1010.1 & 12.13 & 1021.8 & 10.33 & & & & \\
1006.0 & 12.36 & 1032.2 & 9.90 & & & & \\
999.0 & 12.71 & 981.1 & 12.16 & & & &
\end{tabular}




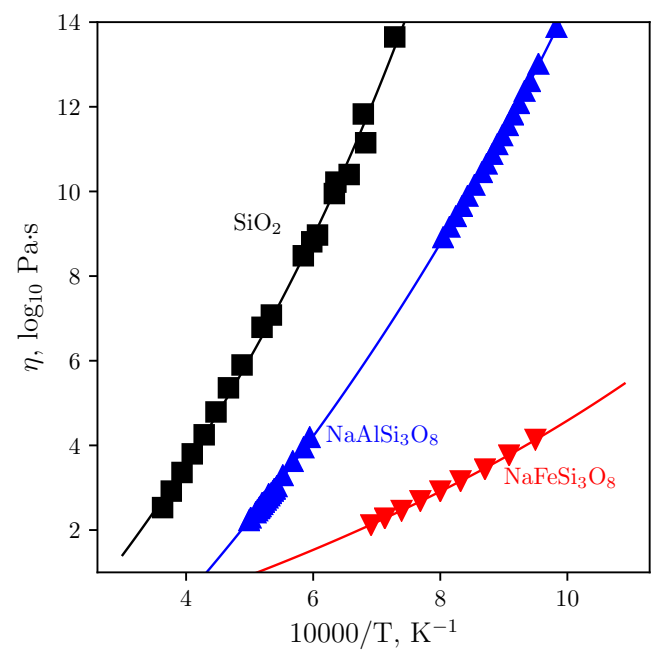

Figure 6. Viscosity of $\mathrm{SiO}_{2}, \mathrm{NaAlSi}_{3} \mathrm{O}_{8}$ and $\mathrm{NaFeSi}_{3} \mathrm{O}_{8}$ melts. Data from (Hetherington et al., 1964; Urbain et al., 1982; Le Losq \& Neuville, 2013; D. Dingwell et al., 1988)

multicomponent basalt and rhyolite melts (Chevrel et al., 2013; Di Genova, Vasseur, et al., 2017). Interestingly, the change of the melt viscosity at given temperature as a function of the iron oxidation state further depends on the metal cation in the melt (Figure 7b), illustrating the interplay between metal cations and $\mathrm{Fe}^{3+}$ for charge compensation.

Close to the glass transition, data from Liebske et al. (2003) suggest a large viscosity decrease, of nearly 2 orders of magnitude, when $\mathrm{Fe}^{3+} / \mathrm{Fe}^{\mathrm{TOT}}$ decreases from 0.6 down to 0.2 in andesitic melts (Fig. 7A). Similarly, Chevrel et al. (2013) estimated that the viscosity of depolymerized $\mathrm{CaO}-\mathrm{Al}_{2} \mathrm{O}_{3}-\mathrm{Fe}_{2} \mathrm{O}_{3}-\mathrm{SiO}_{2}$ melts, analogous to basalts, was decreasing of $\sim 1 \log$ unit with decreasing $\mathrm{Fe}^{3+} / \mathrm{Fe}^{\mathrm{TOT}}$ from 0.67 to 0.18 at the calorimetric glass transition temperature. The effect of the iron oxidation state on the melt viscosity is more important near the glass transition, because, as mentioned previously, chemical and structural effects strongly affect the melt configurational entropy, and hence, viscosity at undercooled temperatures (Neuville \& Richet, 1991; Richet \& Neuville, 1992).

To dive deeper in such concepts, we can use the Adam and Gibbs (1965) theory, which describes viscous flow as a cooperative rearrangement of molecular subunits in the melt. Writing the melt viscosity $\eta$ as

$$
\log _{10} \eta=A_{e}+\frac{B_{e}}{T\left(S^{c o n f}\left(T_{g}\right)+\int_{T_{g}}^{T} C_{p}^{\text {conf }} / T d T\right)}
$$

with $A_{e}$ a constant, $B_{e}$ a term proportional to the energy barriers opposed to the movement of the molecular subunits, $S^{\text {conf }}\left(T_{g}\right)$ the configurational entropy of the melt at the glass transition temperature $T_{g}$, and $C_{p}^{c o n f}$ the configurational heat capacity of the melt. actually, the term $S^{\text {conf }}\left(T_{g}\right)+\int C_{p}^{\text {conf }} / T d T$ is the configurational entropy of the melt at the temperature T, $S^{\operatorname{conf}}(T)$. Close to the glass transition, $S^{\text {conf }}\left(T_{g}\right)$ is important, implying that melt structure will be particularly influencial on viscous movements (e.g. see Le Losq \& Neuville, 2017). As temperature increases, the term $\int C_{p}^{\text {conf }} / T d T$ increases and the melt viscous flow becomes dominated by this term that actually reflect the effect of $\mathrm{T}$ on the frequency of $\mathrm{T}-\mathrm{O}$ bond exchanges (with $\mathrm{T}$ network former cations). Adoption this vision allows understanding the effect of iron oxidation state on melt viscosity: close to the glass transition, in supercooled melts, the different structural environments of $\mathrm{Fe}^{2+}$ and $\mathrm{Fe}^{3+}$ will influence $S^{\text {conf }}\left(T_{g}\right)$, and, hence, will drive large changes in $\eta$. 

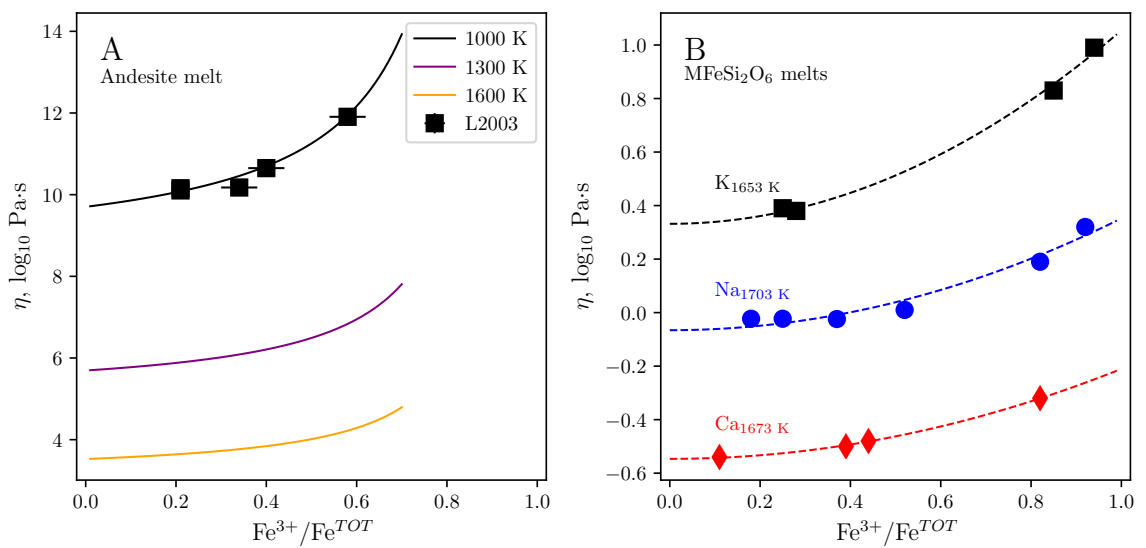

Figure 7. Isothermal viscosity as a function of the oxidation state of iron of A) an andesite melt close to the glass transition and B) of ferrosilicate melts at superliquidus temperatures. In A), curves are calculated from the model of Vetere et al. (2008), and symbols are data from Liebske et al. (2003). In B), curves are polynomial fits to the data from D. B. Dingwell and Virgo (1987, 1988); D. B. Dingwell (1991).

The influence of the iron oxidation state on melt viscosity remains not well constrained, such that the numbers of models that take it into account are limited. Vetere et al. (2008) proposed an equation for andesite melts that allows calculating their viscosity as a function of temperature, water content and iron oxidation state. Their model allows predictions affected by errors lower than $0.17 \mathrm{log}$ units, but is only valid for $\mathrm{Fe}^{3+} / \mathrm{Fe}^{\mathrm{TOT}}$ values lower than 0.7 . For a broader range of compositions, we can further cite the parametric model of Duan (2014), which attempts to take into account effects of composition, pressure, water concentration and iron oxidation state in the modeling of the viscosity of natural magmas. However, predictions from such model should be interpreted with care, because the dataset that includes the effect of iron oxidation state, particularly close to the glass transition, is very limited and may be biased by experimental errors. Indeed, the study of iron-bearing geologic melts always has faced the trouble of crystallization, explaining the scarcity of data on the effect of iron oxidation state on magma viscosity.

\section{Influences on Crystallization and Degassing in Magmatic Systems}

In natural systems, crystallization generally enrich the liquid in $\mathrm{Fe}^{3+}$ as olivine and clinopyroxene preferentially incorporate $\mathrm{Fe}^{2+}$ in their lattice. Therefore, crystallization of the latter minerals will play an important role in affecting the overall redox condition of the system. Crystallization of iron-bearing oxides can further have a significant influence on the residual melt oxidation state. For instance, superficial magnetite crystallization leading to reduction of the residual melt has been proposed by Oppenheimer et al. (2011) to explain why the lava in the lava lake of Mt Erebus in Antartica is more reduced than the melt inclusions recording the oxidation state of the magma at deeper condition (conduit / superficial magma chambers). In all cases, crystallization of Fe-bearing phases will change the major element composition of the residual melt, its iron oxidation state, and the magma crystal content. The latter effect induces order of magnitude changes in magma viscosity, as shown in Fig. 8A. It is affected by the shape and size of crystals, such that crystallization of small phases like spinels may be particularly effective in affecting magma viscosity. In addition to this physical effect, the decrease in the 
iron content of the residual melt further participates in increasing magma viscosity at isothermal conditions. Building on such idea, Di Genova, Kolzenburg, et al. (2017) proposed, for example, that iron-depletion of magmas by nanolite crystallization could be an important mechanism to drive changes in the rheology of magmas and the dynamic of eruptions of silicic volcanic systems.
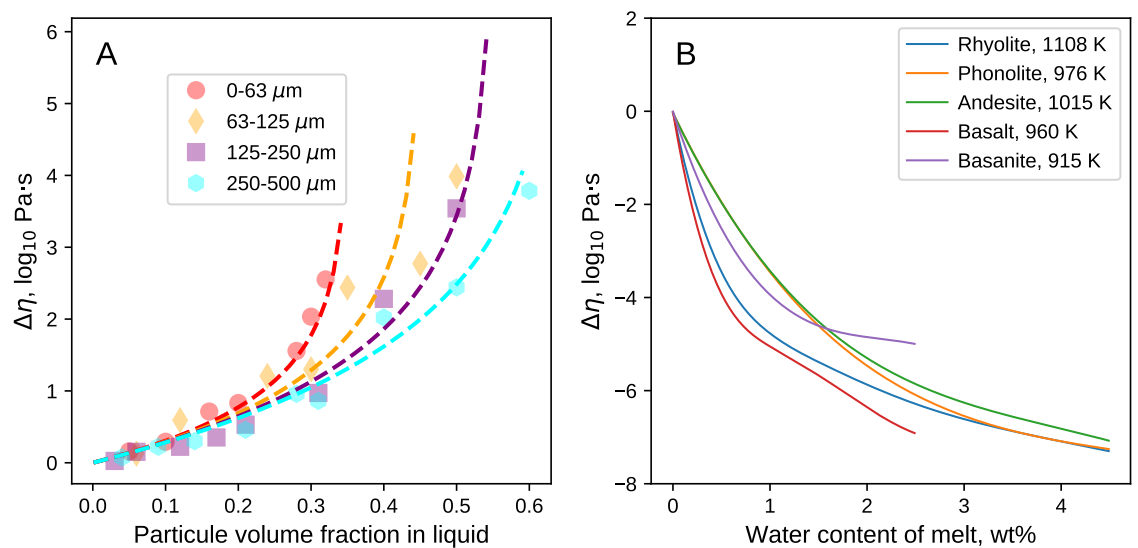

Figure 8. Effects of the crystal (A) and water (B) contents on the viscosity of magmas at constant temperature.(A) Experiments from Del Gaudio et al. (2013) on sanidine and pyroxene crystals in silicon oil show a significant effect of the size of crystals on the relative viscosity of the oil $\left(\Delta \eta=\eta_{\text {crystallized }} / \eta_{\text {crystal-free }}\right)$. (B) Change in the viscosity of magmas as a function of their water content at supercooled temperatures $\left(\Delta \eta=\eta_{\text {water-bearing }} / \eta_{\text {water-free }}\right)$. Curves are calculated for bubble- and crystal-free magmas using equations from (Giordano \& Dingwell, 2003) for a basalt magma of Mt Etna (Italy), (Whittington et al., 2000) for a basanite composition, (Vetere et al., 2006) for an andesite composition, (Le Losq, Neuville, et al., 2015) for the phonolite magma of Mt Erebus (Antartica), and (Le Losq, 2012) for the rhyolite melt of the 3.1 Ma ingimbritic eruption of the Mt Dore (France).

In addition to crystallization, changes in volatile content and speciation in magmatic systems needs to be taken into account as they can further modify the oxidation state of silicate melts. Water has been shown to have only a limited effect on iron oxidation state in closed systems (Moretti, 2005; Carmichael, 1991). However, the initial concentration of water in melts is of critical importance, because water dissolved in magmas affects their viscosity by several orders of magnitude regardless of composition (Fig. 8B). Sulfur and carbon are present in concentrations much lower than that of water, but as they are redox sensitive elements, they play an important role on the magma oxidation state. As a consequence, the relationships between magma oxidation state and volatile speciation should be studied considering a multicomponent C-O-S-H gas-magma system (e.g. (Moretti \& Papale, 2004)). When doing so, significant changes in the magma oxygen fugacity upon magma degassing can be predicted (Moretti \& Papale, 2004; Burgisser \& Scaillet, 2007). In particular, the interactions between Fe and S are particularly important as the degassing of $\mathrm{H}_{2} \mathrm{~S}$ and $\mathrm{SO}_{2}$ can lead to changes in the melt oxidation state, and, hence, $\mathrm{Fe}^{3+} / \mathrm{Fe}^{\text {TOT }}$. This, in turn, will result in a feedback loop as the melt oxidation state will further influence that of the gas. There is thus a melt-gas equilibria in closed systems, or disequilibra in open systems, that needs to be taken into account for infering variations of the melt and gas oxidation states in degassing volcanic environments. To briefly extend on sulfur in magmas, in addition to interplays of $\mathrm{Fe}$ and $\mathrm{S}$ 
during degassing, the complex interplays between the magma $\mathrm{fO}_{2}$ and its sulfur concentration needs to be mentioned. Indeed, while reduced magmas can contain a few hundred ppm of sulfur as $\mathrm{S}^{2-}$ before sulfide saturation, the solubility of sulfur as $\mathrm{S}^{6+}$ at oxidized condition is much higher, of a few thousands ppm at anhydrite saturation (see Baker \& Moretti, 2011, for a review). Interestingly, magnetite saturation in the melt, which depends on its water concentration, can trigger large changes in the sulfur oxidation state (and thus solubility) as S and Fe form a redox couple in the melt as previously described in equation 15, which can be re-written in an oxyde form as (Métrich et al., 2009):

$$
\mathrm{SO}_{4}^{2-}+8 \mathrm{Fe}^{2+} \mathrm{O}=\mathrm{S}^{2-}+8 \mathrm{Fe}^{3+} \mathrm{O}_{1.5}
$$

Crystallization of magnetite extracting preferentially $\mathrm{Fe}^{3+}$ from the melt will drive the melt $\mathrm{Fe}^{3+} / \mathrm{Fe}^{\text {TOT }}$ to a decrease, this resulting in shifting eq. 18 to the right, and, hence, will trigger reduction of sulfur, and possibly sulfur saturation and precipitation of sulfide phases (Jenner et al., 2010). Similarly, S degassing will also affect the equilibrium constant of eq. 18 and, hence, it may alter the iron oxidation state in the melt.

As a result of the interplays between magma oxidation state, crystallization and degassing, the influence of the magma oxidation state on the mobility of magmas and the dynamic of volcanic eruptions is plural. Crystallization will affect the major element chemistry of the residual melt, including volatile content, as well as its oxidation state. In addition, it will add a fraction of solid inclusions in the melt. The combination of those effect will affect the effective viscosity of the magma. Degassing can further perturbate the melt's iron redox state, but, maybe more importantly, it will lead to decreasing the melt water content, this being accompanied of significant changes in the rheology of the magma (Fig. 8B) because of the destructing effects of water on melt polymerisation (e.g. see (Le Losq, Mysen, \& Cody, 2015)). The combination of all those effects is very difficult to study and to model simultaneously (e.g. see (Pistone et al., 2012)). To highlight possible volcanic outcomes of such effects, we will conclude this part by focusing on the interplay between oxygen fugacity, magma crystallization and rheology.

Experiments in iron-bearing magmatic liquids always faced the problem of crystallization. The presence of iron reduces the undercooled metastable temperature domain in which the melt can be kept free from any crystals. Neuville et al. (1993) noticed this effect while studying the viscosity and heat capacity of andesite and rhyolite melts: they noticed the appearance of magnetite crystals of a scale of $100 \mathrm{~nm}$ in the andesite composition after annealing it at $1000 \mathrm{~K}$ in air during 24 hours. Nanolites of hercynite $\left(\mathrm{FeAl}_{2} \mathrm{O}_{4}\right)$ spinels and trydimite also were observed in an andesite composition rich in iron by Linard and Neuville (2000), affecting viscosity measurements (Fig. 9). TEM observation of the andesite glass after the experiments revealed crystallization of $\sim 25 \mathrm{vol} \%$ of nanolites (tablets of $200 \times 100 \times 20 \mathrm{~nm}$; Fig. 9A); the crystallization of hercynite and tridymite phases was metastable, but drove changes in the melt composition toward a rhyolitic one. This effect, combined with that due to crystal addition (Fig. 8A), induced a large increase in the melt viscosity, for instance of more than $1.5 \log$ unit when starting the dynamic isothermal crystallization-viscosity experiment at $1120 \mathrm{~K}$ (Fig. 9B).

The case of cystallisation of nanocrystals in magmatic melts during viscosity experiments was later reported by Liebske et al. (2003) and Villeneuve et al. (2008). Liebske et al. (2003) observed the crystallization of nanolites of magnetites of a size of 10 to 50 $\mathrm{nm}$ in andesite melts at undercooled temperatures. Villeneuve et al. (2008) later observed a similar phenomenon when performing viscosity experiments on a basalt composition at undercooled temperatures. Starting from a crystal-free glass, the authors began the viscosity experiments close to the glass transition $\left(\log (\eta) \sim 10^{12} \mathrm{~Pa} \cdot s ; \mathrm{Fig} .9 \mathrm{C}\right)$. With gradually increasing temperature and measuring viscosity at the same time, they observed the occurence of crystallization of nanolites of spinel phases at $\sim 975 \mathrm{~K}$. Clinopyroxene 
A
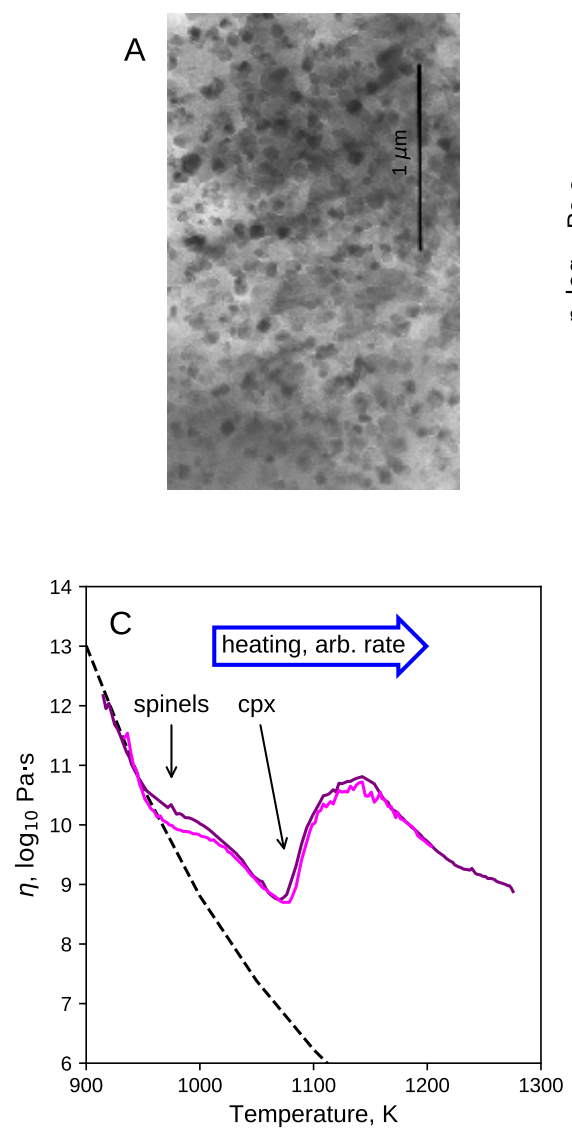
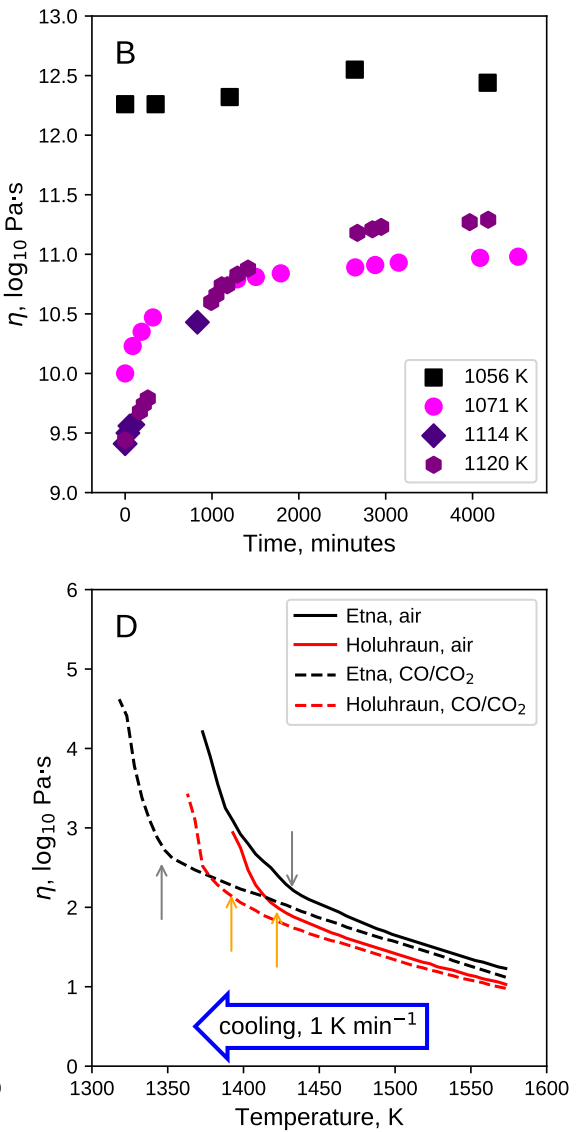

Figure 9. Viscosity, crystallinity and oxidation state of andesite and basalt magmas. (A) Colorized TEM picture of an andesite (ANDE060) glass from Linard and Neuville (2000) after viscosity measurements, containing $\sim 25$ vol\% of hercynite and trydimite nanocrystals; the size of the tablets are approximatively $200 \times 100 \times 10 \mathrm{~nm}$. (B) Viscosity of the crystallizing andesite (ANDE060) melt from Linard and Neuville (2000) as a function of time. The small changes of the viscosity at $1056 \mathrm{~K}$ reflect the absence of extensive crystallization. The two continuous lines are two series of measurements, and the black dotted line is the viscosity of the crystal-free basalt. (C) Viscosity of the Piton de la Fournaise (France) basalt erupted in 1998, measured with increasing temperature at arbitrary rate. Arrows annotated spinels and cpx (clinopyroxene) indicated the onset of the crystallization of those phases while increasing temperature. (D) Viscosity of basalts from Etna (Italie) and Holuhraun (Island) measured with decreasing T from $1573 \mathrm{~K}$ at a rate of $1 \mathrm{~K} \mathrm{~min}^{-1}$; arrows highlight the onset of crystallization, which changes with the oxygen fugacity at which the experiments were performed (air, or $\mathrm{CO} / \mathrm{CO}_{2}$ in a $40 / 60$ ratio). Data from Linard and Neuville (2000); Villeneuve et al. (2008); Kolzenburg et al. (2018).

crystallization occurred at higher temperature, $\sim 1075 \mathrm{~K}$, causing a sharp increase in melt viscosity related to the presence of crystals as well as changes in residual melt composition, including iron oxidation state as clinopyroxene crystallization preferentially removes $\mathrm{Fe}^{2+}$. As Fe, $\mathrm{Ca}$ and $\mathrm{Mg}$ were removed from the residual melt, its degree of polymerisation increased, this resulting in increasing its viscosity of orders of magnitudes. Such chemical change magnifies the physical effect of the crystals on the magma viscos- 
ity. At higher temperatures, Kolzenburg et al. (2018) recently reported experiments where viscosity variations during the crystallization of basaltic melts upon cooling at constant rate were measured (Fig. 9D). Those authors varied the $f_{2}$ of the experiments, and results show that the onset of crystallization upon cooling is displaced to lower temperatures under reduced conditions. Those dynamic undercooling experiments are interesting as they are representative of non-equilibrium conditions encountered during the uprise of magmas in volcanic conduits. In those experiments, the system cools down at cooling rates representative of those in natural systems, such that the degree of undercooling increases continuously, leading to an evolution of the sample crystalline state different from that that would be observed under equilibrium conditions. Such approach is of particular interest for studying the rheological evolution of lava flows, as those systems are continuously loosing heat and, hence, present a degree of undercooling that increases with time. According to Kolzenburg et al. (2018), considering such dynamic evolution of the lava crystallinity is necessary to make representative predictions of the rheology of the lavas, this allowing to improve calculations of the runaway distances of lava flows for instance.

In all cases, the presence of Fe-bearing nanolites in experiments on natural samples highlights (i) the importance of iron and its crystalline phases in natural magmatic systems, and (ii) the difficulty of obtaining crystal-free samples with iron-bearing compositions and to measure their properties at under-cooled temperatures in the laboratory, as the presence of iron enhances crystallization. In particular, one should note that the synthesis of nanolite-free samples in the laboratory requires firing the melts at high temperatures to enhance the reactivity of spinel phases, because those are quite insoluble in silicate melts. Their reaction with the melt can further exhibit a complex behaviour. For instance, the dissolution of high-alumina spinels at $1600{ }^{\circ} \mathrm{C}$ in calcium aluminosilicate melts is indirect, with a $\mathrm{Ca}-\mathrm{Al}$ phase that forms at the melt-crystal interface as an intermediate phase that allows dissolution of alumina into the melt (Sarpoolaky et al., 2003). Therefore, samples fired at too low temperature, even above the liquidus, or for a time too short may still contain nanolite crystals, invisible under the microscope (either binocular or scanning electron microprobe), which can affect in fine any data acquired on such products. The presence of small particules is of particular importance for rheology measurements, as the link between the particle concentration and the liquid viscosity is affected by particle size.

\section{Concluding Remarks}

Iron is a multivalent element present in concentrations ranging from $\sim 1$ to more than $15 \mathrm{wt} \%$ in magmas. It plays a critical role on the phase diagram as well as on dynamic and thermodynamic properties of magmas, and, as such, is a key component for understanding the evolution of magmatic systems.

The review we performed showed the following key points about iron in silicate melts and glasses:

- In the melt structure, $\mathrm{Fe}^{3+}$ is a weak network former and $\mathrm{Fe}^{2+}$ is a network modifier.

- $\mathrm{Fe}^{3+}$ and $\mathrm{Fe}^{2+}$ both participate in decreasing the melt viscosity; $\mathrm{Fe}^{2+}$ has a stronger effect on viscosity compared to $\mathrm{Fe}^{3+}$.

- $\mathrm{Fe}^{3+}$ and $\mathrm{Fe}^{2+}$ have different partial molar volumes, such that magma density depends on iron content and oxidation state.

- Most data suggest that $\mathrm{Fe}^{3+}$ is mostly present in $\mathrm{CN} 4-5$ and $\mathrm{Fe}^{2+}$ in $\mathrm{CN} 5-6$, but the diversity of results reported in litterature suggest a mixture of environments with $\mathrm{CN} 4$ to 6 , and perhaps higher at high pressure. 

$73(1), 167-213$.

Berry, A. J., Stewart, G. A., O'Neill, H. S. C., Mallmann, G., \& Mosselmans, J. F. W. (2018). A re-assessment of the oxidation state of iron in MORB glasses. Earth and Planetary Science Letters, 483, 114-123.

Bézos, A., \& Humler, E. (2005). The $\mathrm{Fe}^{3+} / \sum F e$ ratios of MORB glasses and their implications for mantle melting. Geochimica et Cosmochimica Acta, 69(3), $711-725$.

Borisov, A., Behrens, H., \& Holtz, F. (2015). Effects of melt composition on $\mathrm{Fe}^{3+} / \mathrm{Fe}^{2+}$ in silicate melts: a step to model ferric/ferrous ratio in multicomponent systems. Contributions to Mineralogy and Petrology, 169(2).

Borisov, A., Behrens, H., \& Holtz, F. (2017). Effects of strong network modifiers on $\mathrm{Fe}^{3+} / \mathrm{Fe}^{2+}$ in silicate melts: an experimental study. Contributions to Mineralogy and Petrology, 172(5).

Borisov, A., Behrens, H., \& Holtz, F. (2018). Ferric/ferrous ratio in silicate melts: a new model for $1 \mathrm{~atm}$ data with special emphasis on the effects of melt composition. Contributions to Mineralogy and Petrology, 173(12), 98.

Borisov, A., \& McCammon, C. (2010). The effect of silica on ferric/ferrous ratio in silicate melts: An experimental study using Mossbauer spectroscopy. American Mineralogist, 95(4), 545-555.

Bottinga, Y., \& Weill, D. F. (1970). Densities of liquid silicate systems calculated from partial molar volumes of oxide components. American Journal of Science, 269(2), 169-182.

Bottinga, Y., Weill, D. F., \& Richet, P. (1982). Density calculations for silicate liquids. I. Revised method for aluminosilicate compositions. Geochimica et Cosmochimica Acta, 46(6), 909-919.

Brounce, M. N., Kelley, K. A., \& Cottrell, E. (2014). Variations in $\mathrm{Fe}^{3+} / \sum F e$ of Mariana arc basalts and mantle wedge $f \mathrm{O}_{2}$. Journal of Petrology, 55(12), $2513-2536$.

Burgisser, A., \& Scaillet, B. (2007). Redox evolution of a degassing magma rising to the surface. Nature, 445(7124), 194-197.

Calas, G., \& Petiau, J. (1983). Coordination of iron in oxide glasses through highresolution K-edge spectra: Information from the pre-edge. Solid State Communications, 48(7), 625-629.

Carmichael, I. S. E. (1991). The redox states of basic and silicic magmas: a reflection of their source regions? Contributions to Mineralogy and Petrology, $106(2), 129-141$.

Chevrel, M. O., Giordano, D., Potuzak, M., Courtial, P., \& Dingwell, D. B. (2013). Physical properties of $\mathrm{CaAl}_{2} \mathrm{Si}_{2} \mathrm{O}_{8}-\mathrm{CaMgSi}_{2} \mathrm{O}_{6}-\mathrm{FeO}-\mathrm{Fe}_{2} \mathrm{O}_{3}$ melts: Analogues for extra-terrestrial basalt. Chemical Geology, 346, 93-105.

Cicconi, M. R., Giuli, G., Ertel-Ingrisch, W., Paris, E., \& Dingwell, D. B. $\quad$ (2015). The effect of the $[\mathrm{Na} /(\mathrm{Na}+\mathrm{K})]$ ratio on Fe speciation in phonolitic glasses. American Mineralogist, $100(7), 1610-1619$.

Del Gaudio, P., Ventura, G., \& Taddeucci, J. (2013). The effect of particle size on the rheology of liquid-solid mixtures with application to lava flows: Results from analogue experiments. Geochemistry Geophysics, Geosystems, 14(8), 2661-2669.

Densem, N. E., \& Turner, W. E. S. (1938). Equilibrium Between Ferrous and Ferrous Oxides in Glasses. Journal of the society of glass technology, 22, 372-389.

Di Genova, D., Kolzenburg, S., Wiesmaier, S., Dallanave, E., Neuville, D. R., Hess, K. U., \& Dingwell, D. B. (2017). A compositional tipping point governing the mobilization and eruption style of rhyolitic magma. Nature, 552(7684), 235-238.

Di Genova, D., Vasseur, J., Hess, K.-U., Neuville, D. R., \& Dingwell, D. B. (2017). Effect of oxygen fugacity on the glass transition viscosity and structure of 
silica- and iron-rich magmatic melts. Journal of Non-Crystalline Solids, 470 , 78-85.

Dickenson, M. P., \& Hess, P. C. (1982). Redox equilibria and the structural role of iron in alumino-silicate melts. Contributions to Mineralogy and Petrology, 78 (3), 352-357.

Dingwell, D., Brearley, M., \& Virgo, D. (1988). The dual role of ferric iron in liquid silicates: Effects on density \& viscosity. Chemical Geology, 70(1-2), 86.

Dingwell, D. B. (1989). Shear viscosities of ferrosilicate liquids. American Mineralogist, 74 (9-10), 1038-1044.

Dingwell, D. B. (1991). Redox viscometry of some Fe-bearing silicate melts. American Mineralogist, 76 (9-10), 1560-1562.

Dingwell, D. B., Brearley, M., \& Dickinson, J. E. (1988). Melt densities in the $\mathrm{Na}_{2} \mathrm{O}-\mathrm{FeO}-\mathrm{Fe}_{2} \mathrm{O}_{3}-\mathrm{SiO}_{2}$ system and the partial molar volume of tetrahedrallycoordinated ferric iron in silicate melts. Geochimica et Cosmochimica Acta, 52(10), 2467-2475.

Dingwell, D. B., \& Virgo, D. (1987). The effect of oxidation state on the viscosity of melts in the system $\mathrm{Na}_{2} \mathrm{O}-\mathrm{FeO}-\mathrm{Fe}_{2} \mathrm{O}_{3}-\mathrm{SiO}_{2}$. Geochimica et Cosmochimica Acta, 51(2), 195-205.

Dingwell, D. B., \& Virgo, D. (1988). Viscosities of melts in the $\mathrm{Na}_{2} \mathrm{O}-\mathrm{FeO}-\mathrm{Fe}_{2} \mathrm{O}_{3}$ $\mathrm{SiO}_{2}$ system and factors controlling relative viscosities of fully polymerized silicate melts. Geochimica et Cosmochimica Acta, 52(2), 395-403.

Drickamer, H. G., Bastron, V. C., Fisher, D. C., \& Grenoble, D. C. (1970). The high-pressure chemistry of iron. Journal of Solid State Chemistry, 2(1), 94104.

Duan, X. (2014). A model for calculating the viscosity of natural iron-bearing silicate melts over a wide range of temperatures pressures, oxygen fugacites, and compositions. American Mineralogist, 99(11-12), 2378-2388.

Duffy, J. A. (1993). A review of optical basicity and its applications to oxidic systems. Geochimica et Cosmochimica Acta, 57(16), 3961-3970.

Duffy, J. A., \& Ingram, M. D. (1976). Optical basicity - IV a correlation between the Lewis (optical) basicity of oxyanions and the strengths of brønsted acids in aqueous solution. Journal of Inorganic and Nuclear Chemistry, 38(10), 1831-1833.

Dupree, R., Holland, D., \& Williams, D. (1986). The structure of binary alkali silicate glasses. Journal of Non-Crystalline Solids, 81(1-2), 185-200.

Dyar, M. D. (1985). A review of Mössbauer data on inorganic glasses; the effects of composition on iron valency and coordination. American Mineralogist, 70(3-4), 304-316.

Farges, F., Lefrère, Y., Rossano, S., Berthereau, A., Calas, G., \& Brown, G. E. (2004). The effect of redox state on the local structural environment of iron in silicate glasses: a combined XAFS spectroscopy molecular dynamics, and bond valence study. Journal of Non-Crystalline Solids, 344(3), 176-188.

Fincham, C. J. B., \& Richardson, F. D. (1954). The Behaviour of Sulphur in Silicate and Aluminate Melts. Proceedings of the Royal Society A: Mathematical Physical and Engineering Sciences, 223(1152), 40-62.

Flood, H., Förland, T., Sillén, L. G., Linnasalmi, A., \& Laukkanen, P. (1947). The Acidic and Basic Properties of Oxides. Acta Chemica Scandinavica, 1, 592604.

Fraser, D. G. (1975). Activities of trace elements in silicate melts. Geochimica et Cosmochimica Acta, 39(11), 1525-1530.

Fraser, D. G. (1977). Thermodynamic Properties of Silicate Melts. In Thermodynamics in geology (pp. 301-325). Springer Netherlands.

Fudali, R. F. (1965). Oxygen fugacities of basaltic and andesitic magmas. Geochimica et Cosmochimica Acta, 29(9), 1063-1075.

Gaillard, F., Pichavant, M., \& Scaillet, B. (2003). Experimental determination of 
activities of feo and fe2o3 components in hydrous silicic melts under oxidizing conditions. Geochimica et Cosmochimica Acta, 67(22), 4389-4409.

Gale, A., Dalton, C. A., Langmuir, C. H., Su, Y., \& Schilling, J.-G. (2013). The mean composition of ocean ridge basalts. Geochemistry Geophysics, Geosystems, $\mathrm{n} / \mathrm{a}-\mathrm{n} / \mathrm{a}$.

Galoisy, L., Calas, G., \& Arrio, M. A. (2001). High-resolution XANES spectra of iron in minerals and glasses: structural information from the pre-edge region. Chemical Geology, 174(1-3), 307-319.

Gibbons, R. V., Auasus, T. J., \& Rossman, G. R. (1974). A Spectrographic Interpretation of the Shock-Produced Color Change in Rhodonite $\left(\mathrm{MnSiO}_{3}\right)$ : The Shock-Induced Reduction. American Mineralogist, 59, 177-182.

Giordano, D., \& Dingwell, D. (2003). Viscosity of hydrous Etna basalt: implications for Plinian-style basaltic eruptions. Bulletin of Volcanology, 65(1), 8-14.

Giuli, G., Alonso-Mori, R., Cicconi, M. R., Paris, E., Glatzel, P., Eeckhout, S. G., \& Scaillet, B. (2012). Effect of alkalis on the Fe oxidation state and local environment in peralkaline rhyolitic glasses. American Mineralogist, 97(2-3), 468-475.

Giuli, G., Paris, E., Hess, K.-U., Dingwell, D. B., Cicconi, M. R., Eeckhout, S. G., ... Valenti, P. (2011). XAS determination of the Fe local environment and oxidation state in phonolite glasses. American Mineralogist, 96 (4), 631-636.

González-García, D., Behrens, H., Petrelli, M., Vetere, F., Morgavi, D., Zhang, C., \& Perugini, D. (2017). Water-enhanced interdiffusion of major elements between natural shoshonite and high-k rhyolite melts. Chemical Geology, 466, 86-101.

Guillot, B., \& Sator, N. (2007). A computer simulation study of natural silicate melts. Part II: High pressure properties. Geochimica et Cosmochimica Acta, 71 (18), 4538-4556.

Hannoyer, B., Lenglet, M., Dürr, J., \& Cortes, R. (1992). Spectroscopic evidence of octahedral iron (III) in soda-lime silicate glasses. Journal of Non-Crystalline Solids, 151(3), 209-216.

Hetherington, G., Jack, K. H., \& Kennedy, J. C. (1964). The viscosity of vitreous silica. Physic and Chemistry of Glasses, 5, 130-136.

Jackson, W. E., de Leon, J. M., Brown, G. E., Waychunas, G. A., Conradson, S. D., \& Combes, J. M. (1993). High-Temperature XAS Study of $\mathrm{Fe}_{2} \mathrm{SiO}_{4}$ Liquid: Reduced Coordination of Ferrous Iron. Science, 262(5131), 229-233.

Jaupart, C. (1996). Physical models of volcanic eruptions. Chemical Geology, 128(14), 217-227.

Jayasuriya, K. D., O'Neill, H. S. C., Berry, A. J., \& Campbell, S. J. (2004). A Mössbauer study of the oxidation state of Fe in silicate melts. American Mineralogist, 89(11-12), 1597-1609.

Jenner, F. E., \& O'Neill, H. S. C. (2012). Analysis of 60 elements in 616 ocean floor basaltic glasses. Geochemistry Geophysics, Geosystems, 13(2), n/a-n/a.

Jenner, F. E., O'Neill, H. S. C., Arculus, R. J., \& Mavrogenes, J. A. (2010). The Magnetite Crisis in the Evolution of Arc-related Magmas and the Initial Concentration of Au Ag and Cu. Journal of Petrology, 51(12), 2445-2464.

Jephcoat, A., \& Olson, P. (1987). Is the inner core of the Earth pure iron? Nature, $325(6102), 332-335$.

Johnston, W. D. (1964). Oxidation-Reduction Equilibria in Iron-Containing Glass. Journal of the American Ceramic Society, 47(4), 198-201.

Jørgensen, C. (1962). Chemical Bonding. In Absorption spectra and chemical bonding in complexes (pp. 210-243). Elsevier.

Kilinc, A., Carmichael, I. S. E., Rivers, M. L., \& Sack, R. O. (1983a). The ferricferrous ratio of natural silicate liquids equilibrated in air. Contributions to Mineralogy and Petrology, 83(1-2), 136-140.

Kilinc, A., Carmichael, I. S. E., Rivers, M. L., \& Sack, R. O. (1983b). The ferricferrous ratio of natural silicate liquids equilibrated in air.

Contributions to 
Mineralogy and Petrology, 83(1-2), 136-140.

Kolzenburg, S., Di Genova, D., Giordano, D., Hess, K., \& Dingwell, D. (2018). The effect of oxygen fugacity on the rheological evolution of crystallizing basaltic melts. Earth and Planetary Science Letters, 487, 21-32.

Kopcewicz, B., \& Kopcewicz, M. (1992). Seasonal variations of iron concentration in atmospheric aerosols. Hyperfine Interactions, 71(1-4), 1457-1460.

Kress, V. C., \& Carmichael, I. S. E. (1991). The compressibility of silicate liquids containing $\mathrm{Fe}_{2} \mathrm{O}_{3}$ and the effect of composition temperature, oxygen fugacity and pressure on their redox states. Contributions to Mineralogy and Petrology, $108(1-2), 82-92$.

Lange, R. A., \& Carmichael, I. S. (1987). Densities of $\mathrm{Na}_{2} \mathrm{O}-\mathrm{K}_{2} \mathrm{O}-\mathrm{CaO}-\mathrm{MgO}-\mathrm{FeO}-$ $\mathrm{Fe}_{2} \mathrm{O}_{3}-\mathrm{Al}_{2} \mathrm{O}_{3}-\mathrm{TiO}_{2}-\mathrm{SiO}_{2}$ liquids: New measurements and derived partial molar properties. Geochimica et Cosmochimica Acta, 51(11), 2931-2946.

Lange, R. A., \& Carmichael, I. S. E. (1989). Ferric-ferrous equilibria in $\mathrm{Na}_{2} \mathrm{O}-\mathrm{FeO}-$ $\mathrm{Fe}_{2} \mathrm{O}_{3}-\mathrm{SiO}_{2}$ melts: Effects of analytical techniques on derived partial molar volumes. Geochimica et Cosmochimica Acta, 53(9), 2195-2204.

Lauer, H. V., \& Morris, R. V. (1977). Redox Equilibria of Multivalent Ions in Silicate Glasses. Journal of the American Ceramic Society, 60(9-10), 443-451.

Le Losq, C., Mysen, B. O., \& Cody, G. D. (2015). Water and magmas: insights about the water solution mechanisms in alkali silicate melts from infrared Raman, and ${ }^{29} \mathrm{Si}$ solid-state NMR spectroscopies. Progress in Earth and Planetary Science, 2(1).

Le Losq, C., \& Neuville, D. R. (2013). Effect of the Na/K mixing on the structure and the rheology of tectosilicate silica-rich melts. Chemical Geology, 346, 5771.

Le Losq, C., Neuville, D. R., Florian, P., Henderson, G. S., \& Massiot, D. (2014). The role of $\mathrm{Al}^{3+}$ on rheology and structural changes in sodium silicate and aluminosilicate glasses and melts. Geochimica et Cosmochimica Acta, 126, 495-517.

Le Losq, C., Neuville, D. R., Moretti, R., Kyle, P. R., \& Oppenheimer, C. (2015). Rheology of phonolitic magmas - the case of the Erebus lava lake. Earth and Planetary Science Letters, 411, 53-61.

Lee, S. K., Lin, J.-F., Cai, Y. Q., Hiraoka, N., Eng, P. J., Okuchi, T., ... Yoo, C.-S. (2008). X-ray Raman scattering study of $\mathrm{MgSiO}_{3}$ glass at high pressure: Implication for triclustered $\mathrm{MgSiO}_{3}$ melt in Earth's mantle. Proceedings of the National Academy of Sciences, 105(23), 7925-7929.

Le Losq, C. (2012). Rôle des éléments alcalins et de l'eau sur les propriétés et la structure des aluminosilicates fondus et vitreux : implications volcanologiques (Unpublished doctoral dissertation). University Paris VII - Denis Diderot, Paris.

Le Losq, C., Berry, A., Kendrick, M., Neuville, D., \& O’Neill, H. (2019). Determination of the oxidation state of iron in mid-ocean ridge basalt glasses by raman spectroscopy. American Mineralogist, 104, 1032-1049.

Le Losq, C., \& Neuville, D. R. (2017). Molecular structure, configurational entropy and viscosity of silicate melts: Link through the adam and gibbs theory of viscous flow. Journal of Non-Crystalline Solids, 463, 175-188.

Liebske, C., Behrens, H., Holtz, F., \& Lange, R. A. (2003). The influence of pressure and composition on the viscosity of andesitic melts. Geochimica et Cosmochimica Acta, 67(3), 473-485.

Linard, Y., \& Neuville, D. R. (2000). IPGP database. Paris, France.

Liu, Q. (2006). The partial molar volume of $\mathrm{Fe}_{2} \mathrm{O}_{3}$ in alkali silicate melts: Evidence for an average $\mathrm{Fe}^{3+}$ coordination number near five. American Mineralogist, $91(2-3), 385-393$.

McDonough, W. F., \& s. Sun, S. (1995). The composition of the Earth. Chemical Geology, 120(3-4), 223-253. 
Métrich, N., Berry, A. J., O’Neill, H. S. C., \& Susini, J. (2009). The oxidation state of sulfur in synthetic and natural glasses determined by X-ray absorption spectroscopy. Geochimica et Cosmochimica Acta, 73(8), 2382-2399.

Métrich, N., Susini, J., Foy, E., Farges, F., Massare, D., Sylla, L., ... BonninMosbah, M. (2006). Redox state of iron in peralkaline rhyolitic glass/melt: $\mathrm{X}$-ray absorption micro-spectroscopy experiments at high temperature. Chemical Geology, 231(4), 350-363.

Mo, X. (1982). The Partial Molar Volume of $\mathrm{Fe}_{2} \mathrm{O}_{3}$ in Multicomponent Silicate Liquids and the Pressure Dependence of Oxygen Fugacity in Magmas. Mineralogical Magazine, 45(337), 237-245.

Moretti, R. (2005). Polymerisation, basicity, oxidation state and their role in ionic modelling of silicate melts. Annals of Geophysics, 48(4-5).

Moretti, R., \& Ottonello, G. (2003). Polymerization and disproportionation of iron and sulfur in silicate melts: insights from an optical basicity-based approach. Journal of Non-Crystalline Solids, 323(1-3), 111-119.

Moretti, R., \& Papale, P. (2004). On the oxidation state and volatile behavior in multicomponent gas-melt equilibria. Chemical Geology, 213(1-3), 265-280.

Moussallam, Y., Oppenheimer, C., Scaillet, B., Gaillard, F., Kyle, P., Peters, N., ... Donovan, A. (2014). Tracking the changing oxidation state of erebus magmas, from mantle to surface, driven by magma ascent and degassing. Earth and Planetary Science Letters, 393, 200-209.

Mysen, B. O. (1987). Redox equilibria and coordination of $\mathrm{Fe}^{2+}$ and $\mathrm{Fe}^{3+}$ in silicate glasses from ${ }^{57} \mathrm{Fe}$ mossbauer spectroscopy. Journal of Non-Crystalline Solids, 95-96, 247-254.

Mysen, B. O. (2006a). Redox equilibria of iron and silicate melt structure: Implications for olivine/melt element partitioning. Geochimica et Cosmochimica Acta, $70(12), 3121-3138$.

Mysen, B. O. (2006b). The structural behavior of ferric and ferrous iron in aluminosilicate glass near meta-aluminosilicate joins. Geochimica et Cosmochimica Acta, 70(9), 2337-2353.

Mysen, B. O., Virgo, D., Neumann, E.-R., \& Seifert, F. A. (1985). Redox equilibria and the structural states of ferric and ferrous iron in melts in the system CaO$\mathrm{MgO}-\mathrm{Al}_{2} \mathrm{O}_{3}-\mathrm{SiO}_{2}-\mathrm{Fe}-\mathrm{O}$; relationships between redox equilibria, melt structure and liquidus phase equilibria. American Mineralogist, 70(3-4), 317-331.

Mysen, B. O., Virgo, D., \& Seifert, F. A. (1984). Redox equilibria of iron in alkaline earth silicate melts; relationships between melt structure, oxygen fugacity, temperature and properties of iron-bearing silicate liquids | American Mineralogist | GeoScienceWorld. American Mineralogist, 69, 834-847.

Neuville, D. R. (2006). Viscosity structure and mixing in (Ca, Na) silicate melts. Chemical Geology, 229(1-3), 28-41.

Neuville, D. R., Cormier, L., Flank, A.-M., Briois, V., \& Massiot, D. (2004). Al speciation and ca environment in calcium aluminosilicate glasses and crystals by al and ca k-edge x-ray absorption spectroscopy. Chemical Geology, 213(1-3), $153-163$.

Neuville, D. R., Courtial, P., Dingwell, D. B., \& Richet, P. (1993). Thermodynamic and rheological properties of rhyolite and andesite melts. Contributions to Mineralogy and Petrology, 113(4), 572-581.

Neuville, D. R., \& Richet, P. (1991). Viscosity and mixing in molten (Ca Mg) pyroxenes and garnets. Geochimica et Cosmochimica Acta, 55(4), 1011-1019.

Nikolaev, G. S., Borisov, A. A., \& Ariskin, A. A. (1996). Calculation of the Ferric-Ferrous Ratio in Magmatic Melts: Testing and Additional Calibration of Empirical Equations for Various Magmatic Series. Geochemistry International, $34(8), 9$.

O'Neill, H. S. C. (2006). An experimental determination of the effect of pressure on the $\mathrm{Fe}^{3+} / \sum \mathrm{Fe}$ ratio of an anhydrous silicate melt to 3.0 GPa. American Min- 
eralogist, 91 (2-3), 404-412.

Oppenheimer, C., Moretti, R., Kyle, P. R., Eschenbacher, A., Lowenstern, J. B., Hervig, R. L., \& Dunbar, N. W. (2011). Mantle to surface degassing of alkalic magmas at Erebus volcano Antarctica. Earth and Planetary Science Letters, $306(3-4), 261-271$.

Ottonello, G., Moretti, R., Marini, L., \& Zuccolini, M. V. (2001). Oxidation state of iron in silicate glasses and melts: a thermochemical model. Chemical Geology, $174(1-3), 157-179$.

Palme, H., \& O'Neill, H. S. C. (2014). Cosmochemical Estimates of Mantle Composition. In Treatise on geochemistry (pp. 1-39). Elsevier.

Paul, A., \& Douglas, R. W. (1965). Ferrous-ferric equilibrium in binary alkali silicate glasses. Physics and Chemistry of Glasses, 6, 207.

Pistone, M., Caricchi, L., Ulmer, P., Burlini, L., Ardia, P., Reusser, E., ... Arbaret, L. (2012). Deformation experiments of bubble- and crystal-bearing magmas: Rheological and microstructural analysis. Journal of Geophysical Research: Solid Earth, 117(B5), n/a-n/a.

Richet, P., \& Neuville, D. R. (1992). Thermodynamics of Silicate Melts: Configurational Properties. In Thermodynamic data (pp. 132-161). Springer New York.

Rossano, S., Behrens, H., \& Wilke, M. (2007). Advanced analyses of ${ }^{57} \mathrm{Fe}$ Mössbauer data of alumino-silicate glasses. Physics and Chemistry of Minerals, 35(2), 7793.

Sack, R. O., Carmichael, I. S. E., Rivers, M., \& Ghiorso, M. S. (1981). Ferric-ferrous equilibria in natural silicate liquids at 1 bar. Contributions to Mineralogy and Petrology, 75 (4), 369-376.

Sanloup, C. (2016). Density of magmas at depth. Chemical Geology, 429, 51-59.

Sanloup, C., Drewitt, J., Crépisson, C., Kono, Y., Park, C., McCammon, C., ... Bytchkov, A. (2013). Structure and density of molten fayalite at high pressure. Geochimica et Cosmochimica Acta, 118, 118-128.

Sanloup, C., Drewitt, J. W. E., Konôpková, Z., Dalladay-Simpson, P., Morton, D. M., Rai, N., ... Morgenroth, W. (2013). Structural change in molten basalt at deep mantle conditions. Nature, 503(7474), 104-107.

Sarpoolaky, H., Zhang, S., \& Lee, W. E. (2003). Corrosion of high alumina and near stoichiometric spinels in iron-containing silicate slags. Journal of the European Ceramic Society, 23(2), 293-300.

Schreiber, H. D. (1980). Properties of redox ions in glasses: An interdisciplinary perspective. Journal of Non-Crystalline Solids, 42(1-3), 175-183.

Schreiber, H. D. (1986). Redox processes in glass-forming melts. Journal of NonCrystalline Solids, 84(1-3), 129-141.

Schreiber, H. D. (1987). An electrochemical series of redox couples in silicate melts: A review and applications to geochemistry. Journal of Geophysical Research, 92(B9), 9225.

Schreiber, H. D., Kochanowski, B. K., Schreiber, C. W., Morgan, A. B., Coolbaugh, M., \& Dunlap, T. G. (1994). Compositional dependence of redox equilibria in sodium silicate glasses. Journal of Non-Crystalline Solids, 177, 340-346.

Shiraishi, Y., Ikeda, K., Tamura, A., \& Saito, T. (1978). On the viscosity and density of the molten $\mathrm{FeO}-\mathrm{SiO}_{2}$ system. Transactions of the Japan Institute of Metals, 19(5), 264-274.

Sossi, P., Nebel, O., Anand, M., \& Poitrasson, F. (2016). On the iron isotope composition of mars and volatile depletion in the terrestrial planets. Earth and Planetary Science Letters, 449, 360-371.

Sun, N., Stixrude, L., de Koker, N., \& Karki, B. B. (2011). First principles molecular dynamics simulations of diopside $\left(\mathrm{CaMgSi}_{2} \mathrm{O}_{6}\right)$ liquid to high pressure. Geochimica et Cosmochimica Acta, 75 (13), 3792-3802.

Tangeman, J. A., Lange, R., \& Forman, L. (2001). Ferric-ferrous equilibria in $\mathrm{K}_{2} \mathrm{O}-\mathrm{FeO}-\mathrm{Fe}_{2} \mathrm{O}_{3}-\mathrm{SiO}_{2}$ melts. Geochimica et Cosmochimica Acta, 65(11), 
1809-1819.

Urbain, G., Bottinga, Y., \& Richet, P. (1982). Viscosity of liquid silica, silicates and alumino-silicates. Geochimica et Cosmochimica Acta, 46(6), 1061-1072.

Vetere, F., Behrens, H., Holtz, F., \& Neuville, D. R. (2006). Viscosity of andesitic melts - new experimental data and a revised calculation model. Chemical Geology, 228(4), 233-245.

Vetere, F., Behrens, H., Schuessler, J. A., Holtz, F., Misiti, V., \& Borchers, L. (2008). Viscosity of andesite melts and its implication for magma mixing prior to Unzen 1991-1995 eruption. Journal of Volcanology and Geothermal Research, 175(1-2), 208-217.

Villeneuve, N., Neuville, D. R., Boivin, P., Bachèlery, P., \& Richet, P.

(2008). Magma crystallization and viscosity: A study of molten basalts from the Piton de la Fournaise volcano (La Réunion island). Chemical Geology, 256(3-4), $242-251$.

Virgo, D., \& Mysen, B. O. (1985). The structural state of iron in oxidized vs. reduced glasses at $1 \mathrm{~atm}$ : A ${ }^{57} \mathrm{Fe}$ Mossbauer study. Physics and Chemistry of Minerals, 12(2), 65-76.

Wang, P., \& Drickamer, H. G. (1973). Reduction of $\mathrm{Cu}(\mathrm{II})$ at high pressure. The Journal of Chemical Physics, 59(2), 713-717.

Wang, Y., Sakamaki, T., Skinner, L. B., Jing, Z., Yu, T., Kono, Y., .. Sutton, S. R. (2014). Atomistic insight into viscosity and density of silicate melts under pressure. Nature Communications, 5(1).

Waychunas, G. A., Brown, G. E., Ponader, C. W., \& Jackson, W. E. (1988). Evidence from X-ray absorption for network-forming $\mathrm{Fe}^{2+}$ in molten alkali silicates. Nature, 332(6161), 251-253.

Whittaker, E. J. W., \& Muntus, R. (1970). Ionic radii for use in geochemistry. Geochimica et Cosmochimica Acta, 34 (9), 945-956.

Whittington, A., Richet, P., \& Holtz, F. (2000). Water and the viscosity of depolymerized aluminosilicate melts. Geochimica et Cosmochimica Acta, 64 (21), $3725-3736$.

Wilke, M., Farges, F., Partzsch, G. M., Schmidt, C., \& Behrens, H. (2007). Speciation of Fe in silicate glasses and melts by in-situ XANES spectroscopy. American Mineralogist, 92(1), 44-56.

Yarger, J. L., Smith, K. H., Nieman, R. A., Diefenbacher, J., Wolf, G. H., Poe, B. T., \& McMillan, P. F. (1995). Al Coordination Changes in High-Pressure Aluminosilicate Liquids. Science, 270 (5244), 1964-1967.

Zhang, H., Cottrell, E., Solheid, P. A., Kelley, K. A., \& Hirschmann, M. M. (2018). Determination of $\mathrm{Fe}^{3+} / \sum F e$ of XANES basaltic glass standards by Mössbauer spectroscopy and its application to the oxidation state of iron in MORB. Chemical Geology, 479, 166-175.

Zhang, H., Hirschmann, M. M., Cottrell, E., \& Withers, A. C. $\quad$ (2017). Effect of pressure on $\mathrm{Fe}^{3+} / \sum F e$ ratio in a mafic magma and consequences for magma ocean redox gradients. Geochimica et Cosmochimica Acta, 204, 83-103.

Zhang, Y., Ni, H., \& Chen, Y. (2010). Diffusion data in silicate melts. Reviews in Mineralogy and Geochemistry, 72(1), 311-408. 